Stock Markets, Banks, and Economic Growth

Ross Levine

Sara Zervos

\section{Do well-functioning stock}

markets and banks promote long-term economic growth? Yes, but stock markets and banks differ in the financial services they provide.

The World Bank

Policy Research Department

Finance and Private Sector Development Division December 1996 


\section{Summary findings}

Using data on 49 countries from 1976 to 1993 , Levine and Zervos investigate whether measures of stock market liquidity, size, volatility, and integration in world capital markets predict future rates of economic growth, capital accumulation, productivity improvements, and private savings.

They find that stock market liquidity - as measured by stock trading relative to the size of the market and economy - is positively and significantly correlated with current and future rates of economic growth, capital accumulation, and productivity growth, even after controlling for economic and political factors.
Stock market size, volatility, and integration are not robustly linked with growth. Nor are financial indicator: closely associated with private savings rates.

Significantly, measures of both stock market liquidity and banking development - as measured by bank loans to private enterprises divided by GDP - both predict future rates of growth, capital accumulation, and productivity growth when entered together in regressions.

These results are consistent with the views that (1) financial markets and institutions provide important services for long-run growth, and (2) stock markets and banks provide different financial services.

This paper - a product of the Finance and Private Sector Development Division, Policy Research Department — is part of a larger effort in the department to understand the links between the financial system and economic growth. The study was funded by the Bank's Research Support Budget under the research project "Stock Market Development and Financial Intermediary Growth" (RPO 679-53). Copies of this paper are available free from the World Bank, $1818 \mathrm{H}$ Street NW', Washington, DC 20433. Please contact Paulina Sintim-Aboagye, room N9-030, telephone 202-473-8526, fax 202-52i1155, Internet address psintimaboagye@worldbank.org. December 1996. (44 pages)

The Policy Research Working Paper Series disseminates the findings of work in progress to encourage the exchange of ideas about development issues. An objective of the series is to get the findings out quickly, even if the presentations are less than fully palished. The papers carry the names of the authors and should be cited accordingly. The findings, interpretations, and conclusions expressed in this paper are entirely those of the author. They do not necessarily represent the view of the World Bank, its Executive Directors, or the countries they represent. 


\title{
Stock Markets, Banks, and Economic Growth
}

\author{
Ross Levine \\ World Bank \\ Sara Zervos \\ BZW Securities
}

* The findings, interpretations, and conclusions are the authors' own and should not be attributed to the World Bank, its Executive Board of Directors, or any of its member countries. We thank Mark Baird, Valerie Bencivenga, John Boyd, Jerry Caprio, Asli Demirguc-Kunt, Doug Diamond, John Boyd, Bill Easterly, Michael Gavin, and Bruce Smith for helpful suggestions. We received excellent assistance and comments from Michelle Barnes. 

Considerable debate exists on the relationships between the financial system and economic growth. Historically, economists have focused on banks. Walter Bagehot (1873) and Joseph Schumpeter (1911) emphasize the critical importance of the banking system in economic growth and highlight circumstances when banks can actively spur innovation and future growth by identifying and funding productive investments. In contrast, Robert Lucas (1988) states that economists 'badly over-stress' the role of the financial system, and Joan Robinson (1952) argues that banks respond passively to economic growth. Empirically, Robert King and Ross Levine (1993a) show that the level of financial intermediation is a good predictor of long-run rates of economic growth, capital accumulation, and productivity improvements.

Besides the historical focus on banking, there is an expanding theoretical literature on the links between stock markets and long-run growth, but very little empirical evidence. Levine (1991) derives a model where more liquid stock markets -- markets where it is less expensive to trade equities -- reduce the disincentives to investing in long duration projects because investors can easily sell their stake in the project if they need their savings before the project matures. Enhanced liquidity, therefore, facilitates investment in longer-run, higher-return projects that boost economic growth. Similarly, Michael Devereux and Gregor Smith (1994) and Maurice Obstfeld (1994) show that greater international risk-sharing through internationally integrated stock markets induces a portfolio shift from safe, low-return investments to riskier, high-return investments, thereby accelerating long-run growth. These liquidity and risk models, however, also imply that greater liquidity and international capital market integration ambiguously affect saving rates. In fact, saving rates could fall enough such that growth rates may actually slow with more liquidity and international integration. The debate about market liquidity runs even deeper. Some argue that liquidity can spur investors to research firms since they can quickly 
exploit this information in liquid markets (Albert Kyle 1984), and some argue that liquid markets improve corporate control by facilitating efficient managerial compensation contracts (Bengt Holmstrom and Jean Tirole 1993) and takeovers (David Scharfstein 1988). In contrast, others suggest that market liquidity may create disincentives for expending private resources to research firms since this information is quickly revealed in public prices (Joseph Stiglitz 1985), and others note that excessive liquidity may hinder costly monitoring of managers by making it easy to sell one's stake in the firm (Amar Bhide 1993). ${ }^{1}$ In terms of market volatility, Bradford DeLong et al. (1989) argue that "excessive" stock market volatility can hinder investment, but important disagreement continues over the existence and effects of excessive volatility. ${ }^{2}$ Thus, theoretical debate persists over the links between economic growth and the functioning of stock markets. This paper empirically investigates whether measures of stock market liquidity, size, volatility, and integration with world capital markets are robustly correlated with current and future rates of economic growth, capital accumulation, productivity improvements, and saving rates using data on 49 countries from 1976 through 1993. This investigation provides empirical evidence on the major theoretical debates regarding the linkages between stock markets and long-run economic growth. Moreover, we integrate this study into recent cross-country research on financial intermediation and growth by extending the King and Levine (1993a) analysis of banking and growth to include measures of the functioning of stock markets. Specifically, we evaluate whether banking and stock market indicators are both robustly correlated with current and future rates of economic growth, capital accumulation, productivity growth and private

\footnotetext{
1 On the market's positive role, see Douglas Diamond and Robert Verrecchia (1982), Michael Jensen and Kevin J. Murphy (1990), and Jeremy Stein (1988). Alternatively, see Andrei Shleifer and Lawrence Summers (1988), Morck et al. (1990) and Shleifer and Robert Vishny (1986). See Levine's(1997) review.

${ }^{2}$ See Allan Kleidon (1986) and Robert Shiller (1981).
} 
saving. If they are, then this suggests that both banks and stock markets have an independent empirical connection with contemporaneous and future long-run growth rates.

We find that stock market liquidity -- as measured both by the value of stock trading relative to the size of the market and by the value of trading relative to the size of the economy -is positively and significantly correlated with current and future rates of economic growth, capital accumulation, and productivity growth. Stock market liquidity is a robust predictor of real per capita GDP growth, physical capital growth, and productivity growth after controlling for initial income, initial investment in education, political stability, fiscal policy, openness to trade, and macroeconomic stability. Moreover, the level of banking development -- as measured by bank loans to private enterprises divided by GDP -- also enters these regressions significantly. Banking development and stock market liquidity are both good predictors of economic growth, capital accumulation, and productivity growth. Neither market liquidity nor banking development is significantly related to private saving rates. Importantly, these results do not reflect the potentially forward looking nature of stock prices. When we control for stock prices, our measures of stock market liquidity remain statistically significant and economically important predictors of economic performance.

The other stock market indicators do not have a robust link with long-run growth. Volatility is insignificantly correlated with growth in most specifications. Similarly, market size and international integration are not robustly linked with growth, capital accumulation, productivity improvements, and private saving rates.

The results have implications for a variety of theoretical models. The strong, positive connections between stock market liquidity and faster rates of growth, productivity 
improvements, and capital accumulation confirm Levine's (1991) theoretical predictions. We do not find any support, however, for theories that more liquid or more internationally integrated capital markets negatively affect saving and growth rates. ${ }^{3}$ Further, the evidence does not support the belief that stock return volatility is negatively associated with long-run growth. Finally, the data also suggest that banks provide different services from those of stock markets. Measures of both banking development and stock market liquidity enter the growth regression significantly. Thus, to understand the relationship between financial systems and economic growth, we need theories in which stock markets and banks arise simultaneously to provide different bundles of financial services.

A few points are worth emphasizing in interpreting the results. First, since Levine and David Renelt (1992) show that past researchers have been unable to identify empirical links between growth and macroeconomic indicators that are robust to small changes in the conditioning information set, we check the sensitivity of the results to changes in a large conditioning information set. Stock market liquidity and banking development are positively and robustly correlated with current and future rates of economic growth even after controlling for many other factors associated with economic growth. Second, almost all previous crosscountry studies of growth focus on data where both the dependent and explanatory variables are averaged over the entire sample period. Besides examining this contemporaneous relationship, we also study whether stock market and banking development measured at the beginning of the

3 See Valerie Bencivenga and Bruce Smith (1991) and Obstfeld (1994) for parameter values that lead to lower saving and growth rates with greater liquidity or risk sharing respectively. The data are inconsistent with these parameter values. Note, however, that these models have parameter values that are consistent with our empirical findings that (a) liquidity is positively associated with economic growth and (b) neither liquidity nor international capital market integration is associated with private saving rates. 
period robustly predict future rates of economic growth, capital accumulation, productivity growth, and private saving rates. We find that stock market liquidity and banking development both predict long-run growth, capital accumulation, and productivity improvements. Although this investigation does not establish the direction of causality between financial sector development and growth, the results show that the strong link between financial development and growth does not merely reflect contemporaneous shocks to both, that stock market and banking development do not simply follow economic growth, and that the predictive content of the financial development indicators does not just represent the forward looking nature of stock prices. This paper's results are certainly consistent with the view that the services provided by financial institutions and markets are important for long-run growth. ${ }^{4}$

Raymond Atje and Boyan Jovanovic (1993) present the only other empirical study of stock markets and economic growth. They find a significant correlation between growth over the period 1980-88 and the value of stock market trading divided by Gross Domestic Product (GDP) for 40 countries. We make several contributions. Besides increasing the number of countries by 20 percent and almost doubling the number of years in the sample, we construct additional measures of stock market liquidity, a measure of stock return volatility, and two measures of stock market integration in world capital markets and incorporate these measures into our study of stock markets, banks, and economic growth. Furthermore, we control for economic, legal, and political factors that may influence growth to gauge the sensitivity of the results to changes in the conditioning information set. Moreover, we control for the potential forward looking nature of

\footnotetext{
4 New microeconomic evidence supports the view that differences in banking and stock market development affect firm and industry performance (Asli Demirguc-Kunt and Vojislav Maksimovic 1996a,b; Raghuram Rajan and Luigi Zingales 1996).
} 
financial prices since we want to gauge whether the functioning of stock markets and banks is tied to economic performance, not whether agents anticipate faster growth. Also, we use the standard cross-country growth regression framework of Robert Barro (1991) to make comparisons with other work easier, systematically test for the importance of influential observations, and correct for heteroskedasticity. Finally, besides the direct link with growth, we also study the empirical connections between stock market development and physical capital accumulation, productivity improvements, and private saving rates.

The next section presents measures of stock market and banking development, as well as four growth indicators -- measures of the rate of economic growth, capital accumulation, productivity growth, and private saving. Section II examines the relationship between the four growth indicators and stock market liquidity, size, volatility, international capital market integration as well as the level of banking development. Section III concludes. 


\section{Measuring Stock Market and Banking Development and the Growth Indicators}

To assess the relationship between economic growth and both stock market and banking development, we need (1) empirical indicators of stock market liquidity, size, volatility, and integration with world capital markets, (2) a measure of banking development, and (3) measures of economic growth and its components. This section first defines six stock market development indicators: one measure of stock market size, two measures of stock market liquidity, a measure of stock market volatility and two measures of stock market integration with world capital markets. Although each of these indicators has shortcomings, using a variety of measures provides a richer picture of the ties between stock market development and economic growth than if we used only a single indicator. Second, we describe the empirical indicator of banking development. The third subsection defines the "growth indicators:" measures of per capita GDP growth, per capita physical capital growth, the ratio of private savings to GDP, and productivity growth. Finally, we present summary statistics on these variables.

\section{A. Stock Market Development Indicators}

1. Size: The market capitalization ratio (MCAP) measures the size of the stock market and equals the value of listed domestic shares divided by GDP. Although large markets do not necessarily function effectively and taxes may distort incentives to list on the exchange, many observers use the market capitalization ratio as an indicator of market development.

2. Liquidity Indicators: We use two related measures of market liquidity. First, the turnover ratio (TOR) equals the total value of domestic shares traded divided by market capitalization. The turnover ratio measures the trading of domestic equities on domestic 
exchanges relative to the size of the market. High turnover is often used as an indicator of low transactions costs. Importantly, a large stock market is not necessarily a liquid market: a large but inactive market will have a large market capitalization ratio but a small turnover ratio.

The second measure of market liquidity is the value traded ratio (TVT), which equals the total value of domestic shares traded on the stock market exchange divided by GDP. While not a direct measure of trading costs or the uncertainty associated with trading on a particular exchange, theoretical models of stock market liquidity and economic growth directly motivate the value traded ratio (Levine 1991; Bencivenga et al. 1995). The value traded ratio measures the organized trading of firm equity as a share of national output and should therefore positively reflect liquidity on an economy-wide basis. The total value traded ratio may be importantly different from the turnover. While the value traded ratio captures trading relative to the size of the economy, turnover measures trading relative to the size of the stock market. Thus, a small, liquid market will have a high turnover ratio but a small value traded ratio. ${ }^{5}$

This paper focuses on evaluating whether the liquidity services provided by a country's stock market are strongly linked with national performance. Thus, unlike much of the literature on liquidity, we do not want to measure whether an individual security enjoys great liquidity. 6

We want to measure the degree to which the stock market provides liquidity services on a

\footnotetext{
${ }^{5}$ Besides these liquidity measures, we also examined the value traded ratio divided by stock return volatility. Large values of this liquidity indicator signal substantial trading relative to price changes. More liquid markets should support more trading with less price movement than less liquid markets (holding all else equal). Unfortunately, there are many fewer countries with data on stock return volatility than trading data Nonetheless, these liquidity indicators also have a positive relationship with future economic growth. [See Annex B, available on request.]

${ }^{6}$ Much of the literature on liquidity focuses on evaluating whether a security's liquidity affects its price and rate of return. A large fraction of the empirical work in this area uses measures of bid-ask spreads to proxy for liquidity (Amihud and Mendelson 1989; Gregory Kadlec and John McConnell 1994). We do not have data on bid-ask spreads for this broad cross-section of countries.
} 
macroeconomic scale. The turnover ratio may not satisfy this objective. A country could have a tiny, liquid market with correspondingly high turnover ratio. This stock market, however, would not be providing significant liquidity to the economy as a whole. Put differently, a tiny, liquid market does not imply that agents can cheaply, quickly, and confidently trade ownership claims of a large percentage of the economy's productive technologies. In contrast, the value traded ratio measures trading relative to the size of the whole economy. It, therefore, provides more information about the aggregate provision of liquidity than the turnover ratio. ${ }^{7}$

Since financial markets are forward looking, the value traded ratio has one potential pitfall. If markets anticipate large corporate profits, stock prices will rise today. This price rise would increase the value of stock transactions and therefore raise the value traded ratio. Problematically, the liquidity indicator would rise without a rise in the number of transactions or a fall in transaction costs. This price effect also plagues the market capitalization ratio. One way to gauge the influence of the price effect is to look at the market capitalization and value traded ratios together. The price effect influences both indicators, but only the value traded ratio is directly related to trading. Therefore, we include both the market capitalization and value traded indicators together in our regressions. If the value traded ratio remains significantly correlated with growth while controlling for the market capitalization ratio, then the price effect is not dominating the relationship between the value traded ratio and growth. A second way to gauge the importance of the price effect is to examine the turnover ratio. The price effect does not

\footnotetext{
7 There is a potential shortcoming with using measures of national stock market liquidity to gauge the degree of liquidity available to an economy. Some theories suggest that economies will benefit from access to a liquid stock market. The physical location of the market is unimportant, however. Put differently, there is little reason to believe that Californian savers and firms would have greater access to liquidity if the New York Stock Exchange moved to Los Angeles. For this paper's purposes, we note that the vast majority of each country's equity is traded on its own exchanges, not in international financial centers. This is especially true for the initial value regressions reported below that use measures of stock market development in 1976.
} 
influence the turnover ratio because stock prices enter the numerator and denominator of the turnover ratio. If the turnover ratio is positively and robustly associated with economic growth, then this implies that the price effect is not dominating the relationship between liquidity and long-run economic growth.

3. International integration measures: Besides liquidity and size, we use two indicators of the degree of integration with world financial markets to provide evidence on theories that link market integration with economic growth (e.g., Devereux and Smith 1994; and Obstfeld 1994). In perfectly integrated markets, capital flows across international borders to equate the price of risk. If capital controls or other barriers impede capital movements, then the price of risk may differ internationally. To compute measures of integration, we use the international capital asset pricing model (CAPM) and the international arbitrage pricing model (APM).

Since these models are well known, we only cursorily outline the estimation procedures. Both asset pricing models imply that the expected return on each asset is linearly related to a benchmark portfolio or linear combination of a group of benchmark portfolios. Following Robert Korajczyk and Claude Viallet (1989, p. 562-564), let P denote the vector of excess returns on a benchmark portfolio. For the CAPM, $\mathrm{P}$ is the excess return on a value-weighted portfolio of common stocks. For the APM, P represents the estimated common factors based on the excess returns of an international portfolio of assets using the asymptotic principal components technique of Gregory Connor and Korajczyk (1986). Given $m$ assets and T periods, consider the following regression:

$$
R_{i, t}=\alpha_{i}+b_{i} P_{t}+\epsilon_{i, t}, \quad i=1,2, \ldots ., m ; t=1,2, \ldots ., T,
$$


where $R_{i, t}$ is the excess return on asset $i$ in period $t$ above the return on a risk free asset or zerobeta asset (an asset with zero correlation with the benchmark portfolio). If stock markets are perfectly integrated, then the intercept in a regression of any asset's excess return on the appropriate benchmark portfolio, $\mathrm{P}$, should be zero:

$$
\alpha_{1}=\alpha_{2}=\ldots=\alpha_{m}=0 .
$$

Rejection of the restrictions defined by (2) may be interpreted as rejection of the underlying asset pricing model or rejection of market integration.

Under the assumption that the CAPM and APM are reasonable models of asset pricing, we interpret estimates of the absolute value of the intercept terms from the multivariate regression (1) as measures of market integration. To compute estimates of stock market integration for each national market, we compute the average of the absolute value of $\alpha_{i}$ across all stocks in each country. Then, we multiply this final value by negative one. Thus, the CAPM and APM measures are designed to be positively correlated with integration. Moreover, Korajczyk (1996) shows that international integration measures will be negatively correlated with higher official barriers and taxes to international asset trading, bigger transaction costs, and larger impediments to the flow of information about firms. ${ }^{8}$

4. Volatility: We measure the volatility of stock returns (VOL) as a twelve-month rolling standard deviation estimate that is based on market returns. We cleanse the return series of monthly means and twelve months of autocorrelations using the procedure defined by William

8 The CAPM and APM measures rely on asset pricing models that the data sometimes rejected as good representations of the pricing of risk. However, these measures provide cross-country information on market integration. For this paper, we seek a numerical index of, for example, by how much more the United States is integrated into world capital markets than Nigeria. We are not concerned with whether the index is based at zero. Thus, even if the integration measures include a constant bias, CAPM and APM still provide sound information on cross-country comparisons of market integration. 
Schwert (1989). Specifically, we estimate a 12th-order autoregression of monthly returns, $R_{t}$, including dummy variables, $\mathrm{D}_{\mathrm{jt}}$, to allow for different monthly mean returns:

$$
R_{1}=\sum_{j=1}^{12} a_{j} D_{j t}+\sum_{k=1}^{12} b_{k} R_{t-k}+v_{t}
$$

We collect the absolute value of the residuals from equation (3), and then estimate a 12 th-order autoregression of the absolute value of the residuals including dummy variables for each month to allow for different monthly standard deviations of returns:

$$
|\hat{v}|=\sum_{j=1}^{12} c_{j} D_{i r}+\sum_{i=1}^{12} d_{k}\left|\hat{v}_{t-k}\right|+\mu
$$

The fitted values from this last equation give estimates of the conditional standard deviation of returns. ${ }^{9}$ We include this measure because of the intense interest in market volatility by academics, practitioners, and policy makers.

\section{B. Banking Development}

An extensive theoretical literature examines the ties between banks and economic activity. 10 Empirically, many analysts use "financial depth," which generally equals liquid liabilities of financial intermediaries divided by GDP as a measure of banking development (King and Levine 1993a,b). Financial depth measures the size of specific liabilities of the

\footnotetext{
${ }^{9}$ Further, as in Schwert (1989), we use iterated weighted least squares estimates, iterating three times between (3) and (4), to obtain more efficient estimates. Stock market index values are from the International Finance Corporation's Emerging Markets Data Base (electronic version) and from the International Monetary Fund's International Financial Statistics.

10 Douglas Diamond (1984), John Boyd and Edward Prescott (1986), and Stephen Williamson (1986) develop models where financial intermediaries -- coalitions of agents -- lower the costs of obtaining information about firms from what those costs would be in atomistic capital markets where each investor must acquire information individually. Based on these core models, King and Levine (1993b) show that, by lowering information costs, financial intermediaries foster more efficient resource allocation and thereby accelerate technological innovation and long-run growth. Jeremy Greenwood and Boyan Jovanovic (1990) develop a model in which financial intermediaries affect and are affected by economic growth.
} 
financial system relative to national output. As noted by King and Levine (1993a), however, financial depth does not measure (a) whether the liabilities are those of banks, the central bank, or other financial intermediaries or (b) where the financial system allocates the funds. Thus, to measure banking development better, we use the variable BANK, which equals the value of loans made by banks to private enterprises divided by GDP. ${ }^{11}$ BANK improves upon financial depth measures of banking development. BANK isolates credit issued by banks, as opposed to credit issued by the central bank, and BANK isolates credit to enterprises, as opposed to credit issued to governments. In our empirical work, we also used measures of financial depth and discuss some of these results below. We focus almost exclusively on the results with BANK.

\section{Channels to Growth}

Besides examining the relationship between these financial development indicators and long-run real per capita GDP growth (GROWTH), we also study two channels through which banks and stock markets may be linked to growth: the rate of physical capital accumulation per capita (CAPITAL) and everything else (PRODUCTIVITY). Specifically, let $Y$ equal real per capital GDP, $\mathrm{K}$ equal the real per capita capital stock, and $\mathrm{Z}$ equal other determinants of per capita output. Thus, $\mathrm{Y}=\mathrm{K}^{\mathrm{K}} \mathrm{Z}$, where $\mathrm{K}$ is a production function parameter. Taking logarithms and differentiating yields GROWTH $=\kappa($ CAPITAL $)+$ PRODUCTIVITY, where CAPITAL is the growth rate of the real per capita capital stock and PRODUCTIVITY is the growth rate of all other factors affecting real per capita GDP growth. To obtain empirical estimates, we (a) compute GROWTH from national accounts data, (b) use CAPITAL from King and Levine

${ }^{11}$ Specifically, we divide line $22 \mathrm{~d}$ by $99 \mathrm{~b}$ from the IMF's International Financial Statistics. 
(1994), and (c) select a value for $\kappa$ to compute PRODUCTIVITY as a residual;

PRODUCTIVITY $=$ GROWTH $-\kappa($ CAPITAL $)$, where $\kappa=0.3 .12$ If CAPITAL accurately reflects changes in physical capital and if capacity utilization remains stable when averaged over 18 years, then PRODUCTIVITY should provide a reasonable conglomerate indicator of technological change, quality advances, and resource allocation enhancements. 13

The last growth indicator we consider is private savings (SAVINGS). We obtain annual data on gross private savings from the Masson et al. (1995) careful study of private savings in developing countries, which is based on the International Monetary Fund's World Economic Outlook Database. Although measuring private savings rates is subject to considerable measurement error, as detailed by Masson et al. (1995), these data offer a unique opportunity to shed empirical light on an important theoretical issue: what is the relationship between private saving rates and stock market liquidity, international risk sharing through integrated capital markets, and the level of banking development?

We term the four variables - GROWTH, CAPITAL, PRODUCTIVITY, and SAVINGS growth indicators. Thus, this paper evaluates the empirical relationship between four growth indicators -- GROWTH, CAPITAL, PRODUCTIVITY, and SAVINGS, the six stock market indicators -- TOR, TVT, MCAP, VOL, CAPM, and APM, and the banking development indicator, BANK.

12 To compute capital stocks, King and Levine (1994) estimate the capital-output ratio for over 100 countries in 1950, data permitting, and then iterate forward using Robert Summers and Alan Heston (1991) real investment data and a depreciation rate of 0.07. We update these estimates through 1990 using Summers and Heston (1993) data. Estimates of the capital share parameter, $\kappa$, typically range between 0.25 and 0.40 (See King and Levine 1994 for citations). We experimented with values in this range, and since the results do not importantly change, we report the results with $\kappa=0.3$.

13 In the regressions, we include a term for investment in human capital. 


\section{Summary Statistics and Correlations}

Table 1 presents summary statistics on the six stock market development indicators, the bank development indicator, and four growth indicators, GROWTH, CAPITAL, PRODUCTIVITY, and SAVINGS. We have data for a maximum of 49 countries over the 19761993 period. The stock market data are from the International Finance Corporation's Emerging Markets Data Base and the International Monetary Fund's International Financial Statistics. Volatility is computed from monthly stock returns and we could get monthly stock returns for 36 countries; these countries are indicated with a " $v$ ". The CAPM and APM integration measures have data for 24 countries over the 1976-1993 period; these countries are indicated with an " $\mathrm{i}$ ". Finally, we were able to collect private savings data for 33 countries; these countries are indicated with an "s". The countries are Argentina(i,v), Australia(i, s, v), Austria(s, v), Bangladesh(s), Belgium(s, v), Brazil(i, v), Canada(s, v), Chile(i, s, v), Colombia(i, s, v), Cote d'Ivoire, Costa Rica(s), Germany(s, v), Denmark(s, v), Egypt(s), Spain(s, v), Finland(s, v), France(s, v), United Kingdom(i, s, v), Greece(i, s, v), Hong Kong, Indonesia(i, s), India(i, s, v), Israel(v), Italy(i, s, v), Jamaica(s), Jordan(i, v), Japan(i, s, v), Korea(i, s, v), Luxembourg, Mexico(i, v), Malaysia(i, s, v), Morocco(s), Nigeria(i, s), The Netherlands(s, v), Norway(s, v), New Zealand(s, v), Pakistan(i, v), Peru, Philippines(i, v), Portugal(i, s, v), Singapore, Sweden(s, v), Sri Lanka, Thailand(i, v), Turkey(s, v), Taiwan(i, v), United States(i, s, v), Venezuela(i, v), and Zimbabwe(i, s, v). Data exist for CAPITAL and PRODUCTIVITY over the 1976-90 period.

Table 1 shows substantial variance among the countries in the growth and financial development indicators. For example, Korea averaged 9.7 percent annual growth over the 19761993 period and had a private savings rate of almost 30 percent of GDP, while Cote d'Ivoire 
grew at -2.5 percent in real per capita terms over the same period and Bangladesh's savings rate was 9 percent of GDP; Taiwan had a total value traded to GDP ratio of 1.2, while Nigeria's total value traded ratio averaged 0.0002 from 1976-1993.

Table 2 presents correlations. Data permitting, we average the data over the 1976-1993 period so that each country has one observation per variable. We compute the correlations for CAPITAL and PRODUCTIVITY using data averaged over the 1976-1990 period. Three correlations are worth highlighting. First, BANK is highly correlated with the growth indicators and all of the stock market indicators. Second, BANK is very highly correlated with MCAP (0.65), which suggests that it will be difficult to distinguish between measures of the overall size of the equity market and the measure of bank credit to private enterprises divided by GDP. Third, the liquidity measures are positively and significantly correlated with GROWTH, CAPITAL, and PRODUCTIVITY at the 0.05 level.

\section{Stock Markets, Banks, and Economic Growth}

This section evaluates whether measures of banking development and stock market liquidity, size, volatility, and integration with world capital markets are robustly correlated with economic growth, capital accumulation, productivity growth, and private saving rates. The first two subsections use least squares regressions to study the ties between the growth indicators and measures of banking development, stock market liquidity, market size, and stock return volatility. The next subsection uses instrumental variables to examine the links between the growth indicators, banking development, and measures of capital market integration. We use 
instrumental variables because the international integration measures are estimated regressors. The final subsection conducts a number of sensitivity checks on the robustness of the results.

\section{A. Framework: Banking, liquidity, size, and volatility}

This subsection uses cross-country regressions to gauge the strength of the partial correlation between each of the four growth indicators -- per capita GDP growth, physical capital accumulation, productivity growth, and private saving rates -- and measures of banking and stock market development. The growth indicators are averaged over the 1976-1993 period. The banking and stock market development indicators are computed at the beginning of the period 1976 (data permitting), and we use the suffix "I" to indicate initial value. There is one observation per country. We organize the investigation around the individual stock market development indicators. Thus, we run the following sixteen basic regressions:

$$
\mathrm{G}(\mathrm{j})=\beta \mathrm{X}+\gamma \mathrm{BANK}+\delta \mathrm{S}(\mathrm{k})+\mathrm{u},
$$

$$
\mathrm{j}=1 \text { to } 4 \text {, and } \mathrm{k}=1 \text { to } 4 \text {, }
$$

where the growth indicator, $G(j)$, is either per capita GDP growth, per person capital stock growth, productivity growth, or the private savings rate averaged over the 1976-1993 period; the initial stock market indicator, $\mathrm{S}(\mathrm{k})$, is either the turnover ratio (TORI), the total value traded ratio (TVTI), the market capitalization ratio (MCAPI), or the volatility measure (VOLI) measured at the beginning of the sample period; BANKI is the initial level of banking development; $\mathrm{X}$ is a set of control variables; $\beta$ is a vector of coefficients on $X, \delta$ is the estimated coefficient on the initial stock market indicator, $\gamma$ is the estimated coefficient on the initial level of banking development, and $\mathrm{u}$ is the error term. 
Traditionally, the growth literature uses growth and explanatory variables averaged over long periods. This approach, however, is frequently criticized because (i) a common shock to the dependent and explanatory variables during the sample period may be driving the empirical findings; and (ii) contemporaneous regressions - regressions using dependent and explanatory variables averaged over the same period -- do not account for the potential endogenous determination of growth and the explanatory variables. In addition to conducting the contemporaneous regressions, we focus on the "initial value" regressions defined in equation (5). ${ }^{14}$ While this analysis does not resolve the issue of causality, the initial value regressions show that the strong relationship between financial development and the growth indicators does not merely reflect contemporaneous shocks to both, and that stock market and banking development do not simply follow economic development.

To assess the strength of the independent relationship between the initial levels of stock market and banking development and the growth variables, we include a wide array of control variables, X. Specifically, we include the logarithm of initial real per capital GDP (LRGDP) and the logarithm of the initial secondary school enrollment rate (LSEC) because theory and evidence suggest an important link between long-run growth and initial income and investment in human capital accumulation (Robert Solow 1956; Lucas 1988; Gregory Mankiw, David Romer, David Weil 1992; Robert Barro and Xavier Sala-i-Martin 1992). The number of revolutions and coups (REV) is included since many authors find that political instability is negatively associated with economic growth (see Barro and Sala-i-Martin 1995 for evidence and citations). We also include a variety of macroeconomic indicators in the conditioning

\footnotetext{
${ }^{14}$ The contemporaneous regressions yield very similar results to the initial value regressions. [See Annex C, available on request.]
} 
information set. The initial values of government consumption expenditures to GDP (GOVI) and inflation (PII) are included because theory and some evidence suggests a negative relationship between macroeconomic instability and economic activity (Stanley Fischer 1993; William Easterly and Sergio Rebelo 1993; and Michael Bruno and Easterly 1995). ${ }^{15}$ Similarly, the initial value of the black market exchange rate premium (BMPI) is part of the $\mathrm{X}$ variables since international price distortions may impede efficient investment decisions and economic growth (David Dollar 1993). Moreover, the black market premium is a general indicator of policy, price, and trade distortions and therefore is a useful variable to use in assessing the independent relationship between the growth indicators and measures of development. ${ }^{16}$ As discussed below, alternative control variables and combinations of $\mathrm{X}$ variables do not materially affect the results on the relationship between financial development and economic growth.

\section{B. Results: Banking, liquidity, size, and volatility}

First, consider the results on stock market liquidity and banking development. Table 3 presents four regressions, where the dependent variable is GROWTH, CAPITAL, PRODUCTIVITY, and SAVINGS respectively and the liquidity measure is the initial turnover ratio (TORI), which measures trading relative to the size of the market. White's heteroskedasticity-consistent standard errors are reported in parentheses. Both the stock market liquidity and banking development indicators enter the GROWTH, CAPITAL, and

PRODUCTIVITY regressions significantly at the 0.05 significance level. The other explanatory

$15 \mathrm{GOV}$ is from the International Financial Statistics and equals central government consumption expenditures divided by GDP. PI equals the rate of change in the GDP deflator.

16 The black market exchange rate data are from Picks Currency Yearbook through the late 1980s and then from World Currency Yearbook (International Currency Analysis, Inc.) 
variables generally enter the regressions as expected. Initial income enters with a significantly negative coefficient and the size of the convergence coefficient is very similar to other studies (Barro and Sala-i-Martin 1995). Secondary school enrollment enters the growth regression positively, while political instability enters with a significantly negative coefficient. Although GOVI and PII enter the growth regression with negative coefficients, they are statistically insignificant, though inflation has a strong negative relationship with capital accumulation and private saving rates. In this sample of countries and with the extensive set of control variables, the black market exchange rate premium does not enter the GROWTH regression significantly, which confirms Levine and Renelt (1992). The growth regression R-square of 0.47 is consistent with other cross-country growth studies (e.g., Barro and Sala-i-Martin 1995). In sum, we find that both the initial level of banking development and the initial level of stock market liquidity have statistically significant relationships with future values of GROWTH, CAPITAL, AND PRODUCTIVITY even after controlling for many other factors associated with long-run economic performance. These results are consistent with the view that stock market liquidity and banks facilitate more efficient resource allocation and long-run growth.

We do not find a statistically significant link between private saving rates and either stock market liquidity or banking development. Although the saving results may be viewed skeptically because there are only 29 observations, studies of stock market liquidity and saving using annual data with 174 observations confirm our results: there is not a systematic association between stock market liquidity and private saving rates (Catherine Bonser-Neal and Kathryn Dewenter 1996). It is also worth noting that these results do not contradict Tullio Jappelli and Marco Pagano's (1994) findings that countries where households are liquidity constrained tend to have 
higher saving rates. In Jappelli and Pagano (1994), "liquidity constrained" means that households find it relatively difficult to obtain mortgages or consumer credit. In contrast, this paper uses the term liquidity to refer to the ease with which agents can trade equities. Taken together, the two sets of findings imply that countries with large impediments to obtaining mortgage and consumer credit tend to have higher saving rates, while the level of activity on a country's stock exchange is unrelated to saving rates. 17 Furthermore, our finding that stock market liquidity is unrelated to private saving rates is fully consistent with our finding that stock market liquidity is positively related to physical capital accumulation. As exemplified in Levine (1991) in a closed economy model, saving rates can be held fixed, yet an increase stock market liquidity induces agents to reallocate savings toward capital producing investments that are longer-run and have higher returns. Thus, saving rates are uncorrelated with liquidity, while stock market liquidity boosts the rate of capital accumulation. Moreover, international capital flows might further weaken the link between domestic saving rates and capital formation.

Besides being statistically significant, the estimated coefficients suggest that the relationships between financial sector development and future rates of long-run growth, capital accumulation, and productivity improvements are economically large. For example, the estimated coefficient implies that a one standard deviation increase in initial stock market liquidity $(0.3)$ would increase per capita growth by 0.8 percent per annum $(0.027 * 0.3)$. Accumulating over 18 years, this implies that real GDP per capita would have been over 15 percent higher by $1994\left(\exp \left\{18^{*} 0.008\right\}\right)$. The estimated coefficient on BANKI also suggests a

17 More generally, Jappelli and Pagano (1994, p. 102) note that the finding that financial development is positively linked with economic growth does not contradict their findings, because they focus on "... the effect of imperfections in the mortgage and consumer credit markets, which have no necessary correlation with the development of lending to firms." 
similarly large economic relationship between banking development and growth. Specifically, a one standard deviation increase in initial banking development (0.5) would increase GROWTH by 0.7 percent per annum $\left(0.013^{*} 0.5\right)$. Taken together, the results imply that if a county had increased both stock market and banking development in 1976 by one standard deviation, then by 1994 real per capita GDP would have been 31 percent larger, the capital stock per person would have been 29 percent higher, and productivity would have been 24 percent greater. These conceptual experiments do not consider the question of causality nor how to change the financial sector. Nonetheless, the examples illustrate the potentially large economic consequences of stock market liquidity and banking development and the potentially large economic costs of impediments to financial sector development.

The total value traded ratio measure of stock market liquidity confirms these findings. Table 4 presents the same type of regressions as in Table 3 except we replace TORI with TVTI. Again, the initial liquidity and banking development indicators are significantly and robustly correlated with future rates of economic growth, capital accumulation, and productivity growth. Again, the estimated coefficients suggest an economically large relationship between initial financial development and future long-run growth rates. For example, the results imply that if in 1976 Mexico had had the sample mean value of TVTI $(0.046)$ instead of its actual value of (0.004), annual per capita growth would have been 0.4 percent faster $(0.1 * 0.04)$, such that GDP per capita would have been 7.5 percent higher by $1994(\exp \{18 * 0.004\})$. The economic implications of a symmetric change in banking are even larger. If Mexico had had the sample mean value of banking development in $1976(0.65)$ instead of its actual value of $(0.13)$, growth would have been 0.7 percent faster per annum $(0.014 * 0.52)$. Combined, these improvements 
in stock market liquidity and banking development in 1976 are consistent with Mexico enjoying 23 percent higher GDP per capita by 1994. The findings in Tables 3 and 4 also provide some information on the relative importance of the CAPITAL and PRODUCTIVITY channels (as in Jose DeGregorio and Pablo Guidotti 1995). For example, a one standard deviation increase in TVTI (0.2) would increase capital per person growth by about $1.9 \%$ per annum and PRODUCTIVITY by $1.5 \%$ per annum. Since growth accounting exercises generally give PRODUCTIVITY a weight that is about twice the weight on physical capital accumulation, the main channel linking financial development with growth runs through PRODUCTIVITY rather than CAPITAL, which is consistent with the findings in Jose DeGregorio and Pablo Guidotti (1995)..$^{18}$ As noted above, the estimated coefficients should not be viewed as exploitable elasticities. Rather, these conceptual experiments are meant to illustrate the economic size of the coefficients.

The forward looking nature of stock prices -- the "price-effect" -- is not driving the strong link between market liquidity and the growth indicators. This can be deduced from two results. First, the price effect does not influence the turnover ratio, and turnover is robustly linked with future rates of economic growth, capital accumulation, and productivity growth. Second, we include the market capitalization ratio and the value traded ratio together in the same regression to test whether the price-effect is producing the strong empirical links between the total value traded ratio and the growth indicators. The price-effect influences both MCAPI and TVTI. If the price-effect is driving the empirical association between the total value traded ratio (TVTI) and the growth indicators reported in Table 4, then TVTI should not

18 The PRODUCTIVITY channel is also the main link between BANKI and GROWTH in the Table 3 and 4 results. 
remain significantly correlated with the growth indicators when we simultaneously include MCAPI and TVTI. This is not the case. As reported in Table 5, TVTI remains significantly correlated with future rates of economic growth, capital accumulation, and productivity growth even when controlling for market capitalization (with little change in the estimated coefficients). Thus, the evidence is inconsistent with the view that expectations of future growth, which are reflected in current stock prices, are driving the strong empirical relationship between stock market liquidity and growth. The evidence is consistent with the view that the ability to trade ownership of an economy's productive technologies easily promotes more efficient resource allocation, capital formation, and faster growth. ${ }^{19}$

Importantly, initial stock market size and stock return volatility are not generally robust predictors of the growth indicators. As shown in Table 6, stock return volatility is not closely linked with future growth, productivity improvements or private saving rates, and volatility is positively correlated with capital accumulation. The results on market size also do not suggest a reliable link to the growth indicators. Although the figures presented in Table 7 indicate a positive association between MCAPI, GROWTH, and CAPITAL, this relationship is strongly influenced by a few countries. Specifically, if Jamaica, Korea, and Singapore are removed from the regression, the P-value on MCAPI rises to $0.1 .^{20}$ As discussed below, the results on market liquidity are much more robust to the removal of outliers. More importantly, the relationship between stock market size and the growth indicators vanishes when controlling for

\footnotetext{
19 The strong link between liquidity and capital accumulation suggests an area for future research. Specifically, three empirical findings need to be reconciled: (1) stock market liquidity is positively tied to capital formation, (2) equity sales do not finance much of this capital formation (Colin Mayer 1988); and (3) stock market liquidity is positively associated with corporate debt-equity ratios in developing countries (Demirguc-Kunt and Maksimovic 1996a). These findings, plus this paper's finding that stock market liquidity is not closely linked with private saving rates, imply interactions between stock markets, banks, corporate finance, and investment allocation decisions that existing theories do not capture (though, see Boyd and Smith 1996).

20 [See Annex D, available on request.]
} 
stock market liquidity (Table 5). Thus, it is not just listing securities on an exchange; it is the ability to trade those securities that is closely tied to economic performance.

\section{International Capital Market Integration, Banking, and the Growth Indicators}

To investigate the relationship between the growth indicators and international capital market integration, we slightly revise the analytical framework in two ways. First, we only have data on capital market integration for 24 countries. Thus, we use pooled cross-section time series data averaged over the 1976-1985 and 1986-1993, so that each country has potentially two observations for a maximum of 48 observations. ${ }^{21}$ Second, the CAPM and APM measures are estimated regressors. Therefore, we use two-stage least squares to derive consistent standard errors as suggested by Adrian Pagan (1984).22

Tables 8 and 9 report the results on capital market integration. We do not detect an independent link between integration and the growth indicators. Moreover, the reported regressions exclude inflation, which is very highly correlated with stock market integration. With inflation included, the P-values on the CAPM and APM measures become even larger. While the small sample may lower confidence in these results, the findings do not support the hypothesis that greater risk sharing through internationally integrated markets affect growth, capital accumulation, productivity growth, or private saving rates.

${ }^{21}$ We choose this asymmetric dividing point because the data for some countries start in 1978.

22 For instruments, we use the logarithm of initial real per capita GDP, the logarithm of the initial secondary school enrollment ratio, the number of revolutions and coups, initial market capitalization ratio, initial total value traded ratio, initial turnover ratio, initial inflation rate, initial ratio of international trade to GDP, initial government consumption to GDP ratio, and initial black market exchange rate premium. 


\section{Sensitivity Analyses}

We conducted a wide array of sensitivity analyses to check the robustness of these results. As mentioned above, regressions using values of the dependent and explanatory variables averaged over the entire sample period yield similar results. ${ }^{23}$ Furthermore, changing the conditioning information set did not materially affect our results. For example, altering the set of explanatory variables included in the regression, adding measures of legal efficiency or institutional development, as defined in Paulo Mauro (1995), or using the King and Levine (1993a) measure of financial depth did not affect the strong link between stock market liquidity and growth. ${ }^{24}$ We also experimented with an alternative measure of stock market liquidity that gauges trading relative to stock price movements. Specifically, we divide the total value traded ratio by the volatility index. All things equal, more liquid markets should be able to support more trading with less price volatility. This alternative measure produced similar results. ${ }^{25}$

We test for the potential influence of outliers in two ways. First, we use the procedure for analyzing the influence of particular observations suggested by David Belsley et al. (1980) and described in William Greene (1993, pp. 287-8). This procedure identifies countries that exert a large effect on each equation's residuals. Using a critical value of 2.5 , we find that removing particularly influential observations does not affect our conclusions. Second, we use a more subjective method for identifying influential observations; we use scatter plots of the partial relationship between each of the growth indicators and the individual stock market indicators to identify outliers that may be excessively influencing the slope and significance of the estimated

\footnotetext{
23 [See Annex C, available on request.]

24 [See Annex A, available on request.]

25 [See Annex B, available on request.]
} 
regression line. ${ }^{26}$ Removing influential observations importantly weakens the relationship between the growth indicators and market size, as noted above. The other results do not change. In particular, stock market liquidity remains robustly correlated with growth, capital accumulation, and productivity growth after removing potential outliers. ${ }^{27}$

We were also concerned about a potential sample selection problem: we only include countries with sufficient stock market activity to warrant inclusion in data bases. We do have data on all the non-stock market data for an additional 29 countries (Bolivia, Botswana, Central African Republic, Cameroon, Dominican Republic, Ecuador, Ethiopia, Ghana, Guatemala, Guyana, Haiti, Kenya, Liberia, Lesotho, Mauritius, Madagascar, Mali, Mauritania, Malawi, Niger, Nicaragua, Paraguay, Rwanda, Senegal, Somalia, Tunisia, Uruguay, Zaire, and Zambia.). Although we do not have explicit observations on stock transactions in these economies, anecdotal information and a review of official documents suggest that stock market activity in these countries was inconsequential in 1976. Thus, for these 29 countries, we enter values of zero for the market capitalization, value trading, and turnover ratios. Zero is not an extreme guess. Recall from Table 1 that the minimum values for the market capitalization, total value traded, and turnover ratios are $0.01,0.0002$, and 0.006 with standard deviations of $0.43,0.19$, and 0.33 respectively. Nonetheless, imposing these values may create statistical problems. Thus, we use weighted least squares regressions. We impose a weight of 1 on all the countries where we have direct stock market data. We impose weights of, alternatively, $0,0.25,0.5,0.75$, and 1 on

\footnotetext{
${ }^{26}$ Specifically, in the multivariate regression of G(i) on $\mathrm{X}$, BANK, and $\mathrm{S}(\mathrm{k})$, the partial scatter plot is computed as follows: regress $G(i)$ on $X$ and BANK and collect the residuals, $U(G(i))$. Regress $S(k)$ on $X$ and BANK and collect the residuals, $U(S(k))$. Then plot $U(G(i))$ against $U(S(k))$. This gives a two-dimensional graph of the relationship between $\mathrm{G}(\mathrm{i})$ and $\mathrm{S}(\mathrm{k})$ controlling for $\mathrm{X}$ and BANK. This helps identify particularly influential observations.

27 [See Annex D, available on request.]
} 
the countries where we enter a zero for the stock market indicators. Thus, readers can choose how much weight they are willing to give to the zero guesses. Table 10 presents the results on the banking and stock market indicators in the growth regression with the different weights. The results indicate that sample selection is not driving the results. Moreover, using these additional countries and weights does not alter the conclusions about the robust links between the financial indicators and CAPITAL and PRODUCTIVITY. The link between initial levels of both stock market liquidity and banking development are strongly linked with future rates of economic growth, capital accumulation, and productivity growth even when adding data on an additional 29 countries and imposing different weights on these observations. ${ }^{28}$

\footnotetext{
28 The results are similar for the CAPITAL and PRODUCTIVITY regressions as shown in Annex E, which is available on request.
} 


\section{Conclusion}

This paper studied the empirical relationship between various measures of stock market development, banking development, and long-run economic growth. We find that, even after controlling for many factors associated with growth, stock market liquidity and banking development are both positively and robustly correlated with contemporaneous and future rates of economic growth, capital accumulation, and productivity growth. This result is consistent with the view that a greater ability to trade ownership of an economy's productive technologies facilitates efficient resource allocation, physical capital formation, and faster economic growth. Furthermore, since measures of stock market liquidity and banking development both enter the growth regressions significantly, the findings suggest that banks provided different financial services from those provided by stock markets. Thus, to understand the relationship between the financial system and long-run growth more comprehensively, we need theories in which both stock markets and banks arise and develop simultaneously while providing different bundles of financial services to the economy. We find no support for the contentions that stock market liquidity, international capital market integration, or stock return volatility reduce private saving rates or hinder long-run growth. This paper finds a strong, positive link between financial development and economic growth and the results suggest that financial factors are an integral part of the growth process. 



\section{REFERENCES}

Amihud, Yakov and Mendelson, Haim. "The Effects of Beta, Bid-Ask Spread, Residual Risk and Size on Stock Returns," Journal of Finance, June 1989, 44(2), pp. 479-86.

Atje, Raymond and Jovanovic, Boyan, "Stock Markets and Development," European Economic Review, April 1993, 37 (2/3), pp. 632-40.

Bagehot, Walter. Lombard Street. Homewood, IL: Richard D. Irwin, 1873 (1962 Edition).

Barro, Robert J. "Economic Growth in a Cross Section of Countries," Quarterly Journal of Economics, May 1991, 56(2), pp. 407-43.

Barro, Robert J. and Sala-i-Martin, Xavier. Economic Growth. New York: McGraw-Hill, 1995.

Belsley, David., et al. Regression Diagnostics: Identifying Influential Data and Sources of Collinearity, New York: Wiley, 1980.

Bencivenga, Valerie R. and Smith, Bruce D. "Financial Intermediation and Endogenous Growth," Review of Economic Studies, April 1991, 58(2), pp. 195-209.

Bencivenga, Valerie R.; Smith, Bruce D., and Starr, Ross M. "Transactions Costs, Technological Choice, and Endogenous Growth," Joumal of Economic Theory, October 1995, 67(1), pp. 53-177.

Bhide, Amar. "The Hidden Costs of Stock Market Liquidity," Journal of Financial Economics, August 1993, 34(2), pp. 31-51.

Bonser-Neal, Catherine and Dewenter, Kathryn. "Does Financial Market Development Stimulate Savings? Evidence From Emerging Market Stock Markets," University of Indiana mimeo, 1996.

Boyd, John H. and Prescott, Edward C. "Financial Intermediary-Coalitions," Journal of Economics Theory, April 1986, 38(2), pp. 211-32.

Boyd, John H. and Prescott, Edward C. "The Coevolution of the Real and Financial Sectors in the Growth Process," World Bank Economic Review, May 1996, 10(2), pp. 371-396.

Bruno, Michael and Easterly, William. "Inflation Crises and Long-Run Growth," World Bank mimeo, 1995. 
Cameron, Rondo; Crisp, Olga; Patrick, Hugh T. and Tilly, Richard, eds. Banking in the Early Stages of Industrialization: A Study in Comparative Economic History. New York:

Oxford University Press, 1967.

Connor, Gregory and Korajczyk, Robert A. "Performance Measurement with the Arbitrage Pricing Theory: A New Framework for Analysis," Journal of Financial Economics, March 1986, 15(3), pp. 373-94.

DeGregorio, Jose and Guidotti, Pablo E. "Financial Development and Economic Growth," World Development, March 1995, 23(3), pp. 433-48.

De Long, J. Bradford; Shleifer, Andrei; Summers, Lawrence H. and Waldmann, Robert J. "The Size and Incidence of the Losses from Noise Trading," Journal of Finance, July 1989, 44 (3), pp. 681-96.

Demirgüç-Kunt, Asli and Maksimovic, Vojislav. "Stock Market Development and Firm Financing Choices." World Bank Economic Review, May 1996a 10(2), pp. 341-70.

Demirgüç-Kunt, Asli and Maksimovic, Vojislav. "Financial Constraints, Uses of Funds, and Firm Growth: An International Comparison," World Bank mimeo, $1996 \mathrm{~b}$.

Devereux, Michael B., and Smith, Gregor, W. "International Risk Sharing and Economic Growth," International Economic Review, August 1994, 35(4), pp. 535-50.

Diamond, Douglas W. "Financial Intermediation and Delegated Monitoring," Review of Economic Studies, July 1984, 51(3), pp. 393-414.

Diamond, Douglas W. and Dybvig, Philip H. "Bank Runs, Deposit Insurance, and Liquidity," Journal of Political Economy, June 1983, 91(3), pp. 401-19.

Diamond, Douglas W. and Verrecchia, Robert E. "Optimal Managerial Contracts and Equilibrium Security Prices," Journal of Finance, May 1982, 37(2), pp. 275-87.

Dollar, David. "Outward-Oriented Developing Economies Really Do Grow More Rapidly: Evidence from 95 LDCs, 1976-1985," Economic Development and Cultural Change, April 1992, 40(3), pp. 523-44.

Easterly, William and Rebelo, Sergio. "Fiscal Policy and Economic Growth: An Empirical Investigation," Journal of Monetary Economics, December 1993, 32(3), pp. 417-58.

Fischer, Stanley. "The Role of Macroeconomic Factors in Growth," Journal of Monetary Economics, December 1993, 32(3), pp. 485-511.

Goldsmith, Raymond, W. Financial Structure and Development. New Haven, CT: Yale University Press, 1969. 
Greenwood, Jeremy and Jovanovic, Boyan. "Financial Development, Growth, and the Distribution of Income," Journal of Political Economy, October 1990, 98 (5, Pt.1), pp. 1076-1107.

Grossman, Sanford J., and Miller, Merton H. "Liquidity and Market Structure," Journal of Finance, July 1988, 43(3), pp. 617-33.

Holmstrom, Bengt, and Tirole, Jean. "Market Liquidity and Performance Monitoring," Journal of Political Economy, August 1993, 101(4), pp. 678-709.

Jappelli, Tullio and Pagano, Marco. "Saving, Growth, and Liquidity Constraints," Quarterly Journal of Economics, February 1994, 109(1), pp. 93-109.

Jensen, Michael C. and Murphy, Kevin J. "Performance Pay and Top-Management Incentives," Journal of Political Economy, April 1990, 98(2), pp. 225-64.

Kadlec, Gregory B. and McConnell, John J. "The Effect of Market Segmentation and Illiquidity on Asset Prices: Evidence from Exchange Listings," Journal of Finance, June 1994, 49(2), pp. 611-36.

King, Robert G. and Levine, Ross. "Finance and Growth: Schumpeter Might Be Right," Quarterly Journal of Economics, August 1993b, 108(3), pp. 717-38.

King, Robert G. and Levine, Ross. "Finance, Entrepreneurship, and Growth: Theory and Evidence," Journal of Monetary Economics, December 1993c, 32(3), pp. 513-42.

Kleidon, Allan W. "Variance Bounds Tests and Stock Price Valuation Models, " Journal of Political Economy, October 1986, 94(5), pp. 953-1001.

Korajczyk, Robert A. "A Measure of Stock Market Integration for Developed and Emerging Markets," World Bank Economic Review, May 1996, 10(2), pp. 267-89.

Korajczyk, Robert A. and Viallet, Claude J. "An Empirical Investigation of International Asset Pricing," Review of Financial Studies, 1989, 2(4), pp. 553-585.

Kyle, Albert S. "Market Structure, Information, Futures Markets, and Price Formation," in International Agricultural Trade: Advanced Readings in Price Formation, Market Structure, and Price Instability eds. Gary G. Storey, Andrew Schmitz and Alexander H. Sarris, Boulder, CO: Westview, 1984.

Levine, Ross. "Stock Markets, Growth, and Tax Policy," Journal of Finance, September 1991, 46(4), pp. 1445-65.

Levine, Ross. "Financial Development and Economic Growth: Views and Agenda," Journal of Economic Literature, forthcoming, 1997. 
Levine, Ross and Renelt, David. "A Sensitivity Analysis of Cross-Country Growth Regressions," American Economic Review, September 1992, 82(4), pp. 942-63.

Lucas, Robert E. "On the Mechanics of Economic Development," Journal of Monetary Economics. July 1988, 22(1), pp. 3-42.

Mankiw, N. Gregory; Romer, David; and Weil, David. "A Contribution to the Empirics of Economic Growth," Quarterly Journal of Economics, May 1992, 107(2), pp. 407-37.

Masson, Paul; Bayoumi, Tamim, and Samiei, Hossein. "Saving Behavior in Industrial and Developing Countries," International Monetary Fund: Staff Studies for the World Economic Outlook, September 1995.

Mauro, Paulo. "Corruption and Growth," Quarterly Journal of Economics, August 1995, 110(3), pp. 681-712.

Mayer, Colin. "New Issues in Corporate Finance," European Economic Review, June 1988, 32(5), pp. 1167-88.

Morck, Randall; Shleifer, Andrei, and Vishny, Robert W. "Do Managerial Objectives Drive Bad Acquisitions?," Journal of Finance, March 1990, 45(1), pp. 31-48.

Obstfeld, Maurice. "Risk-Taking, Global Diversification, and Growth," American Economic Review December 1994, 84(5), pp. 1310-29.

Pagan, Adrian. "Econometric Issues in the Analysis of Regressions with Generated Regressors," International Economic Review, February 1984, 25(1), pp. 221-47.

Rajan, Raghuram G. and Zingales, Luigi. "Financial Dependence and Growth," National Bureau of Economic Research Working Paper Series No. 5758, September 1996.

Robinson, Joan. "The Generalization of the General Theory," in The Rate of Interest and Other Essays, London: Macmillan, 1952.

Ross, Stephen A. "The Arbitrage Theory of Capital Asset Pricing," Journal of Economic Theory, December 1976, 13(3), pp. 341-60.

Saint-Paul, Gilles. "Technological Choice, Financial Markets and Economic Development," European Economic Review, May 1992, 36(4), pp. 763-81.

Scharfstein, David. "The Disciplinary Role of Takeovers," Review of Economic Studies, April 1988, 55(2), pp. 185-99. 
Schumpeter, Joseph A. Theorie der Wirtschaftlichen Entwicklung. Leipzig: Dunker \& Humblot, 1912. [The Theory of Economic Development, 1912, translated by Redvers Opie.

Cambridge, MA: Harvard University Press, 1934.]

Schwert, G. William. "Why Does Stock Market Volatility Change Over Time?" Journal of Finance, December 1989, 49(5), pp. 1115-53.

Shiller, Robert J. "Do Stock Prices Move Too Much to be Justified by Subsequent Changes in Dividends"? American Economic Review, June 1981, 71(3), pp. 421-36.

Shleifer, Andrei and Vishy, Robert W. "Large Shareholders and Corporate Control," Journal of Political Economy, June 1986, 96(3), pp. 461-88.

Shleifer, Andrei and Summers, Lawrence. "Breach of Trust in Hostile Takeovers," in Corporate Takeovers: Causes and Consequences, ed. A. Auerbach, Chicago: University of Chicago Press, 1988, pp. 33-56.

Solow, Robert M. "A Contribution to the Theory of Economic Growth," Quarterly Journal of Economics, February 1956, 70(1), pp. 65-94.

Stein, Jeremy C. "Takeover Threats and Managerial Myopia," Journal of Political Economy, February 1988, 96, pp. 61-80.

Stiglitz, Joseph E. "Credit Markets and the Control of Capital," Journal of Money, Credit and Banking, May 1985, 17(2), pp. 133-52.

Summers, Robert and Heston, Allan. "The Penn World Table (Mark 5): An Expanded Set of International Comparisons, 1950-1988," Quarterly Journal of Economics, May 1991, $106(2)$, pp. 327-368.

Summers, Robert and Heston, Allan. "Penn World Tables, Version5.5," available on diskette from the National Bureau of Economic Research , Cambridge MA, 1993.

Townsend, Robert M. "Optimal Contracts and Competitive Markets with Costly State Verification," Journal of Economic Theory, October 1979, 21(2), pp. 265-93.

Wells, Stephen. "Turnover Statistics and Trade Reporting," London Stock Exchange Quarterly with Quality of Markets Review, Spring 1994, pp. 23-6.

Williamson, Stephen D. "Costly Monitoring, Financial Intermediation, and Equilibrium Credit Rationing," Journal of Monetary Economics, September 1986, 18 (2), pp. 159-79. 
Table 1--Summary Statistics: Annual Averages 1976-1993

\begin{tabular}{ccccccc}
\hline \hline & MEAN & MEDIAN & MAXIMUM & MINIMUM & $\begin{array}{c}\text { STANDARD } \\
\text { DEVIATION }\end{array}$ & OBSERVATIONS \\
\hline GROWTH & 0.021 & 0.019 & 0.097 & -0.025 & 0.022 & 49 \\
CAPITAL & 0.028 & 0.025 & 0.095 & -0.023 & 0.026 & 48 \\
PRODUCTIVITY & 0.016 & 0.014 & 0.079 & -0.019 & 0.017 & 48 \\
SAVINGS & 19.988 & 20.720 & 29.730 & 9.060 & 5.046 & 33 \\
MCAP & 0.31 & 0.17 & 2.45 & 0.01 & 0.43 & 48 \\
TVT & 0.10 & 0.03 & 1.16 & 0.00 & 0.19 & 49 \\
TOR & 0.29 & 0.22 & 2.05 & 0.01 & 0.33 & 48 \\
VOL & 0.07 & 0.05 & 0.31 & 0.03 & 0.06 & 49 \\
BANK & 0.78 & 0.72 & 2.27 & 0.12 & 0.50 & 24 \\
APM & 4.30 & 3.95 & 6.67 & 2.17 & 1.48 & 1.86 \\
CAPM & 4.08 & 3.65 & 9.98 & 2.00 & & 49 \\
\hline
\end{tabular}

Notes: GROWTH=real per capita GDP growth; CAPITAL=real per capita capital stock growth; PRODUCTIVITY=GROWTH-'(0.3)(CAPITAL); SAVINGS=gross private savings divided by GDP;

MCAP=market capitalization; $T V T=$ total value traded as a share of GDP; $T O R=$ value of stock transactions as a share of market capitalization; $\mathrm{VOL}=$ measure of stock return 'volatility; BANK=bank credit to private enterprises as a share of GDP; APM=the arbitrage pricing model measure of stock market integration; $\mathrm{CAPM}=$ the international capital asset pricing model measure of stock market integration. 
Table 2--Correlations

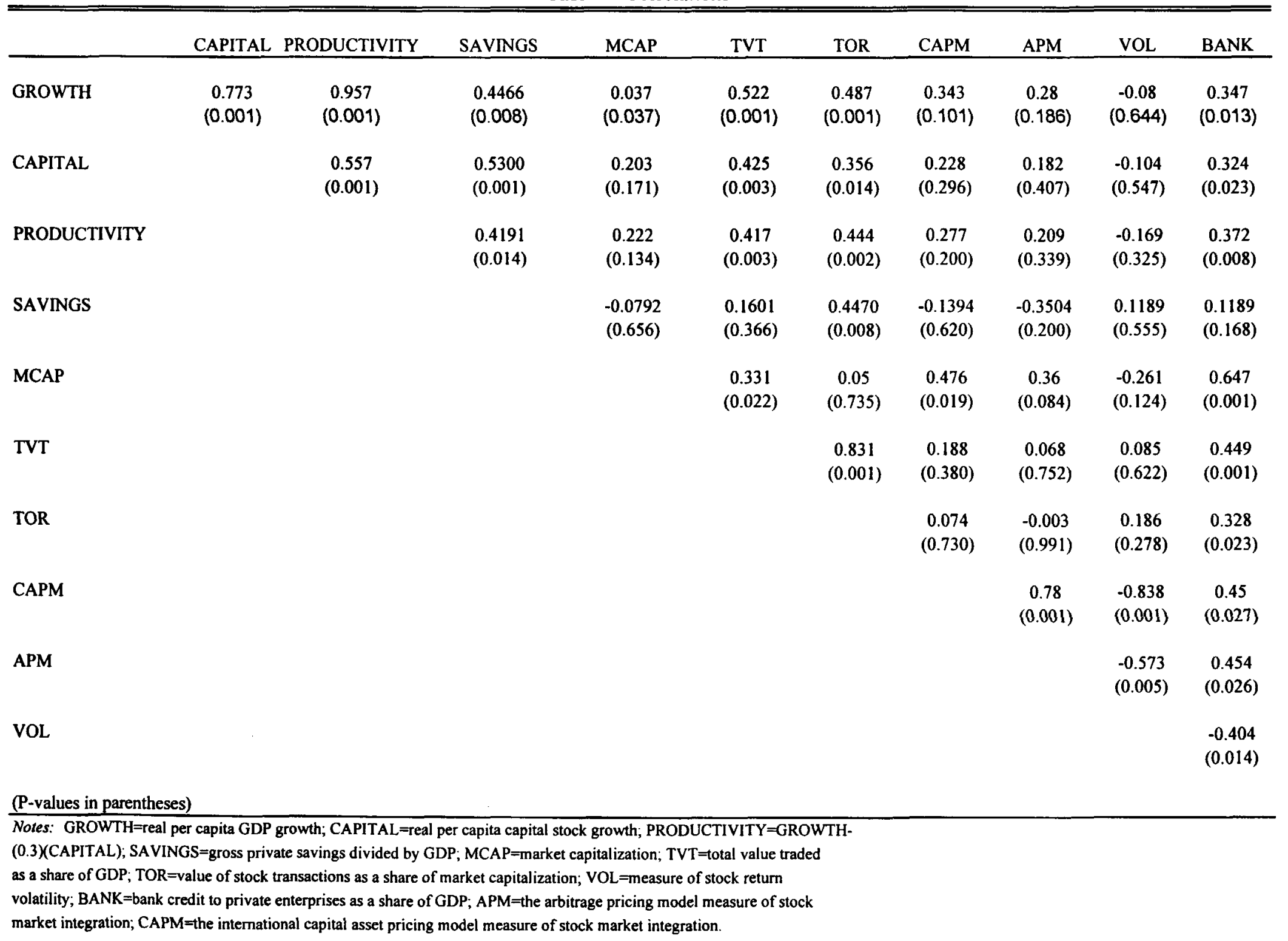


Table 4--Initial Value Traded Ratio, Banks and Growth, 1976-1993

\begin{tabular}{|c|c|c|c|c|}
\hline \multirow[b]{2}{*}{ Independent Variables } & \multicolumn{4}{|c|}{ Dependent Variables } \\
\hline & GROWTH & CAPITAL & PRODUCTIVITY & SAVINGS \\
\hline Constant & $\begin{array}{c}0.0485 \\
(0.0412)\end{array}$ & $\begin{array}{c}0.1044 \\
(0.0060)\end{array}$ & $\begin{array}{c}0.0336 \\
(0.0290)\end{array}$ & $\begin{array}{l}23.4439 \\
(0.0175)\end{array}$ \\
\hline LRGDP & $\begin{array}{c}-0.0140 \\
(0.0143)\end{array}$ & $\begin{array}{c}-0.0118 \\
(0.1376)\end{array}$ & $\begin{array}{c}-0.0076 \\
(0.1072)\end{array}$ & $\begin{array}{c}-1.1258 \\
(0.5853)\end{array}$ \\
\hline LSEC & $\begin{array}{c}0.0230 \\
(0.0904)\end{array}$ & $\begin{array}{c}0.0053 \\
(0.7612)\end{array}$ & $\begin{array}{c}0.0114 \\
(0.3334)\end{array}$ & $\begin{array}{c}2.7878 \\
(0.6187)\end{array}$ \\
\hline REV & $\begin{array}{c}-0.0291 \\
(0.0049)\end{array}$ & $\begin{array}{c}-0.0239 \\
(0.0405)\end{array}$ & $\begin{array}{c}-0.0188 \\
(0.0126)\end{array}$ & $\begin{array}{l}-1.6711 \\
(0.8833)\end{array}$ \\
\hline GOVI & $\begin{array}{c}-0.0763 \\
(0.0984)\end{array}$ & $\begin{array}{c}-0.0181 \\
(0.7426)\end{array}$ & $\begin{array}{c}-0.0510 \\
(0.1727)\end{array}$ & $\begin{array}{l}-31.7011 \\
(0.2057)\end{array}$ \\
\hline PII & $\begin{array}{c}-0.0092 \\
(0.2327)\end{array}$ & $\begin{array}{c}-0.0312 \\
(0.0107)\end{array}$ & $\begin{array}{c}-0.0099 \\
(0.2243)\end{array}$ & $\begin{array}{r}-14.1077 \\
(0.0028)\end{array}$ \\
\hline BMPI & ' & $\begin{array}{l}1002 \\
1473)\end{array}$ & $\begin{array}{c}0.0000 \\
(0.8076)\end{array}$ & $\begin{array}{c}0.0059 \\
(0.8120)\end{array}$ \\
\hline BANKI & $\begin{array}{c}0.0136 \\
(0.0168)\end{array}$ & $\begin{array}{c}0.0140 \\
(0.0233)\end{array}$ & $\begin{array}{c}0.0118 \\
(0.0134)\end{array}$ & $\begin{array}{c}3.3854 \\
(0.2221)\end{array}$ \\
\hline TVTI & $\begin{array}{c}0.0975 \\
(0.0032)\end{array}$ & $\begin{array}{c}0.0931 \\
(0.0051)\end{array}$ & $\begin{array}{c}0.0750 \\
(0.0013)\end{array}$ & $\begin{array}{c}2.2782 \\
(0.8841)\end{array}$ \\
\hline $\begin{array}{c}\mathbf{R}^{2} \\
\text { Observations }\end{array}$ & $\begin{array}{c}0.4561 \\
43\end{array}$ & $\begin{array}{c}0.5030 \\
42\end{array}$ & $\begin{array}{c}0.3671 \\
42\end{array}$ & $\begin{array}{c}0.3358 \\
29\end{array}$ \\
\hline (Heteroskedasticity-consi & $P$-values in $p$ & arentheses) & & \\
\hline $\begin{array}{l}\text { Notes: GROWTH=real per } \\
\text { growth; PRODUCTIVITY= } \\
\text { savings divided by GDP; LR } \\
\text { logarithm of initial secondar } \\
\text { per year; GOVI=initial gover } \\
\text { inflation rate; BMPI=initial b } \\
\text { credit to private enterprises a } \\
\text { as a share of GDP. }\end{array}$ & $\begin{array}{l}\text { GDP growth; } \\
\text { NTH-(0.3)(CA } \\
=\text { logarithm of } i \\
\text { ol enrollment; } \\
\text { it consumption } \\
\text { market exchan } \\
\text { are of GDP; T }\end{array}$ & $\begin{array}{l}\text { CAPITAL=re } \\
\text { PITAL); SAV } \\
\text { nitial real per } \\
\text { REV=numbe } \\
\text { expenditures } \\
\text { ze rate premiv } \\
V T I=\text { initial va }\end{array}$ & $\begin{array}{l}\text { al per capita capital stc } \\
\text { INGS=gross private } \\
\text { capita GDP; LSEC= } \\
\text { of revolutions and co } \\
\text { divided by GDP; PII=i } \\
\text { m; BANKI=initial bar } \\
\text { lue of total value trade }\end{array}$ & $\begin{array}{l}\text { ups } \\
\text { initial } \\
\text { k }\end{array}$ \\
\hline
\end{tabular}


Table 5--Initial Value Traded \& Market Capitalization Ratios, Banks, and Growth,1976-1993

\begin{tabular}{|c|c|c|c|c|}
\hline \multirow[b]{2}{*}{ Independent Variables } & \multicolumn{4}{|c|}{ Dependent Variables } \\
\hline & GROWTH & CAPITAL & PRODUCTIVITY & SAVINGS \\
\hline Constant & $\begin{array}{c}0.0466 \\
(0.0425)\end{array}$ & $\begin{array}{c}0.1021 \\
(0.0079)\end{array}$ & $\begin{array}{c}0.0307 \\
(0.0489)\end{array}$ & $\begin{array}{l}23.1308 \\
(0.0263)\end{array}$ \\
\hline LRGDP & $\begin{array}{c}-0.0146 \\
(0.0104)\end{array}$ & $\begin{array}{c}-0.0123 \\
(0.1290)\end{array}$ & $\begin{array}{c}-0.0084 \\
(0.0869)\end{array}$ & $\begin{array}{c}-0.8337 \\
(0.6979)\end{array}$ \\
\hline LSEC & $\begin{array}{c}0.0253 \\
(0.0610)\end{array}$ & $\begin{array}{c}0.0071 \\
(0.6952)\end{array}$ & $\begin{array}{c}0.0142 \\
(0.2394)\end{array}$ & $\begin{array}{c}2.6155 \\
(0.6554)\end{array}$ \\
\hline REV & $\begin{array}{c}-0.0258 \\
(0.0448)\end{array}$ & $\begin{array}{c}-0.0221 \\
(0.0632)\end{array}$ & $\begin{array}{c}-0.0168 \\
(0.0677)\end{array}$ & $\begin{array}{c}-3.7978 \\
(0.7514)\end{array}$ \\
\hline GOVI & $\begin{array}{c}-0.0701 \\
(0.1134)\end{array}$ & $\begin{array}{c}-0.0143 \\
(0.8004)\end{array}$ & $\begin{array}{c}-0.0509 \\
(0.2008)\end{array}$ & $\begin{array}{c}-36.4692 \\
(0.2002)\end{array}$ \\
\hline PII & $\begin{array}{c}-0.0095 \\
(0.1644)\end{array}$ & $\begin{array}{c}-0.0314 \\
(0.0119)\end{array}$ & $\begin{array}{c}-0.0098 \\
(0.2097)\end{array}$ & $\begin{array}{c}-12.9672 \\
(0.0138)\end{array}$ \\
\hline BMPI & $\begin{array}{c}0.0000 \\
(0.7993)\end{array}$ & $\begin{array}{c}-0.0002 \\
(0.0675)\end{array}$ & $\begin{array}{c}0.0000 \\
(0.7434)\end{array}$ & $\begin{array}{c}0.0105 \\
(0.7197)\end{array}$ \\
\hline BANKI & $\begin{array}{c}0.0076 \\
(0.1770)\end{array}$ & $\begin{array}{c}0.0104 \\
(0.0743)\end{array}$ & $\begin{array}{c}0.0081 \\
(0.0875)\end{array}$ & $\begin{array}{c}3.0241 \\
(0.2779)\end{array}$ \\
\hline MCAPI & $\begin{array}{c}0.0153 \\
(0.0314)\end{array}$ & $\begin{array}{c}0.0096 \\
(0.2954)\end{array}$ & $\begin{array}{c}0.0074 \\
(0.1938)\end{array}$ & $\begin{array}{c}-4.6302 \\
(0.5705)\end{array}$ \\
\hline TVTI & $\begin{array}{c}0.0709 \\
(0.0372)\end{array}$ & $\begin{array}{c}0.0774 \\
(0.0462)\end{array}$ & $\begin{array}{c}0.0594 \\
(0.0143)\end{array}$ & $\begin{array}{c}8.4819 \\
(0.6446)\end{array}$ \\
\hline $\begin{array}{c}\mathbf{R}^{2} \\
\text { Observations }\end{array}$ & $\begin{array}{c}0.4900 \\
42\end{array}$ & $\begin{array}{c}0.5043 \\
41\end{array}$ & $\begin{array}{c}0.3811 \\
41\end{array}$ & $\begin{array}{c}0.3436 \\
29\end{array}$ \\
\hline \multicolumn{5}{|c|}{ (Heteroskedasticity-consistent P-values in parentheses) } \\
\hline \multicolumn{5}{|c|}{$\begin{array}{l}\text { Notes: GROWTH=real per capita GDP growth; CAPITAL=real per capita capital stock growth; } \\
\text { PRODUCTIVITY=GROWTH-(0.3)(CAPITAL); SAVINGS=gross private savings divided by } \\
\text { GDP; LRGDP=logarithm of initial real per capita GDP; LSEC=logarithm of initial secondary schoo } \\
\text { enrollment; REV=number of revolutions and coups per year; GOVI=initial government } \\
\text { consumption expenditures divided by GDP; PII=initial inflation rate; BMPI=initial black market } \\
\text { exchange rate premium; BANKI=initial bank credit to private enterprises as a share of GDP; } \\
\text { MCAPI=initial value of total market capitalization as a share of GDP; TVTI=initial value of total } \\
\text { value traded as a share of GDP. }\end{array}$} \\
\hline
\end{tabular}


Table 6--Initial Market Capitalization Ratio, Banks, and Growth, 1976-1993

\begin{tabular}{|c|c|c|c|c|}
\hline \multirow[b]{2}{*}{ Independent Variables } & \multirow[b]{2}{*}{ Growth } & \multicolumn{2}{|c|}{ Dependent Variables } & \multirow[b]{2}{*}{ Saving } \\
\hline & & Capital & Productivity & \\
\hline Constant & $\begin{array}{c}0.0399 \\
(0.0376)\end{array}$ & $\begin{array}{c}0.0588 \\
(0.1535)\end{array}$ & $\begin{array}{c}0.0333 \\
(0.0833)\end{array}$ & $\begin{array}{l}16.7108 \\
(0.1011)\end{array}$ \\
\hline LRGDP & $\begin{array}{l}-0.0142 \\
(0.0052)\end{array}$ & $\begin{array}{c}-0.0099 \\
(0.1425)\end{array}$ & $\begin{array}{l}-0.0088 \\
(0.0208)\end{array}$ & $\begin{array}{l}-0.1524 \\
(0.9327)\end{array}$ \\
\hline LSEC & $\begin{array}{c}0.0248 \\
(0.0503)\end{array}$ & $\begin{array}{c}0.0112 \\
(0.5015)\end{array}$ & $\begin{array}{c}0.0136 \\
(0.1182)\end{array}$ & $\begin{array}{r}1.0545 \\
(0.8275)\end{array}$ \\
\hline REV & $\begin{array}{l}-0.0189 \\
(0.1871)\end{array}$ & $\begin{array}{c}-0.0117 \\
(0.3410)\end{array}$ & $\begin{array}{l}-0.0124 \\
(0.2230)\end{array}$ & $\begin{array}{c}1.4425 \\
(0.8821)\end{array}$ \\
\hline GOVI & $\begin{array}{l}-0.0386 \\
(0.2972)\end{array}$ & $\begin{array}{c}0.0221 \\
(0.7011)\end{array}$ & $\begin{array}{l}-0.0291 \\
(0.4594)\end{array}$ & $\begin{array}{l}-9.3645 \\
(0.7358)\end{array}$ \\
\hline PII & $\begin{array}{c}-0.0089 \\
(0.1391)\end{array}$ & $\begin{array}{l}-0.0275 \\
(0.0087)\end{array}$ & $\begin{array}{l}-0.0107 \\
(0.3457)\end{array}$ & $\begin{array}{l}-6.8104 \\
(0.3355)\end{array}$ \\
\hline BMPI & $\begin{array}{c}0.0000 \\
(0.5570)\end{array}$ & $\begin{array}{c}-0.0002 \\
(0.1023)\end{array}$ & $\begin{array}{c}0.0000 \\
(0.9637)\end{array}$ & $\begin{array}{c}0.0007 \\
(0.9792)\end{array}$ \\
\hline BANKI & $\begin{array}{c}0.0084 \\
(0.1878)\end{array}$ & $\begin{array}{c}0.0086 \\
(0.2997)\end{array}$ & $\begin{array}{c}0.0091 \\
(0.2659)\end{array}$ & $\begin{array}{c}4.9126 \\
(0.0881)\end{array}$ \\
\hline MCAPI & $\begin{array}{c}0.0238 \\
(0.0009)\end{array}$ & $\begin{array}{c}0.0218 \\
(0.0111)\end{array}$ & $\begin{array}{c}0.0140 \\
(0.1435)\end{array}$ & $\begin{array}{l}-2.3834 \\
(0.7101)\end{array}$ \\
\hline $\begin{array}{c}\mathbf{R}^{2} \\
\text { Observations }\end{array}$ & $\begin{array}{c}0.4213 \\
45\end{array}$ & $\begin{array}{c}0.3471 \\
44\end{array}$ & $\begin{array}{c}0.3128 \\
44\end{array}$ & $\begin{array}{c}0.2308 \\
31\end{array}$ \\
\hline \multicolumn{5}{|c|}{ (Heteroskedasticity-consistent P-values in parentheses) } \\
\hline \multicolumn{5}{|c|}{$\begin{array}{l}\text { Notes: GROWTH=real per capita GDP growth; CAPITAL=real per capita capital } \\
\text { stock growth; PRODUCTIVITY=GROWTH-(0.3)(CAPITAL); SAVINGS=gross } \\
\text { private savings divided by GDP; LRGDP=logarithm of initial real per capita GDP; } \\
\text { LSEC=logarithm of initial secondary school enrollment; } R E V=\text { number of revolutions } \\
\text { and coups per year; GOVI=initial government consumption expenditures divided by } \\
\text { GDP; PII=initial inflation rate; BMPI=initial black market exchange rate premium; } \\
\text { BANKI=initial bank credit to private enterprises as a share of GDP; MCAPI=initial } \\
\text { market capitalization. }\end{array}$} \\
\hline
\end{tabular}


Table 7--Initial Volatility, Banks and Growth: 1976-1993

\begin{tabular}{|c|c|c|c|c|}
\hline \multirow[b]{2}{*}{ Independent Variables } & \multicolumn{4}{|c|}{ Dependent Variables } \\
\hline & GROWTH & CAPITAL & PRODUCTIVITY & SAVINGS \\
\hline Constant & $\begin{array}{c}0.0324 \\
(0.4317)\end{array}$ & $\begin{array}{l}-0.0604 \\
(0.1684)\end{array}$ & $\begin{array}{c}0.0397 \\
(0.3258)\end{array}$ & $\begin{array}{c}8.6693 \\
(0.6284)\end{array}$ \\
\hline LRGDP & $\begin{array}{l}-0.0178 \\
(0.1124)\end{array}$ & $\begin{array}{c}-0.0212 \\
(0.0091)\end{array}$ & $\begin{array}{l}-0.0122 \\
(0.2720)\end{array}$ & $\begin{array}{l}-4.4398 \\
(0.2861)\end{array}$ \\
\hline LSEC & $\begin{array}{c}0.0316 \\
(0.2962)\end{array}$ & $\begin{array}{c}0.0591 \\
(0.0155)\end{array}$ & $\begin{array}{c}0.0186 \\
(0.5255)\end{array}$ & $\begin{array}{l}11.9487 \\
(0.3292)\end{array}$ \\
\hline REV & $\begin{array}{l}-0.0274 \\
(0.1746)\end{array}$ & $\begin{array}{l}-0.0344 \\
(0.0357)\end{array}$ & $\begin{array}{c}-0.0170 \\
(0.3592)\end{array}$ & $\begin{array}{l}-8.3267 \\
(0.0483)\end{array}$ \\
\hline GOVI & $\begin{array}{c}0.0024 \\
(0.9520)\end{array}$ & $\begin{array}{c}0.0327 \\
(0.4466)\end{array}$ & $\begin{array}{l}-0.0100 \\
(0.8428)\end{array}$ & $\begin{array}{l}-17.6932 \\
(0.5022)\end{array}$ \\
\hline PII & $\begin{array}{c}-0.0280 \\
(0.4928)\end{array}$ & $\begin{array}{c}-0.0944 \\
(0.0022)\end{array}$ & $\begin{array}{l}-0.0110 \\
(0.7602)\end{array}$ & $\begin{array}{l}-29.5232 \\
(0.0004)\end{array}$ \\
\hline BMPI & $\begin{array}{c}0.0000 \\
(0.9640)\end{array}$ & $\begin{array}{c}0.0001 \\
(0.5803)\end{array}$ & $\begin{array}{c}0.0000 \\
(0.7420)\end{array}$ & $\begin{array}{c}0.0313 \\
(0.6592)\end{array}$ \\
\hline BANKI & $\begin{array}{c}0.0131 \\
(0.1078)\end{array}$ & $\begin{array}{c}0.0119 \\
(0.2143)\end{array}$ & $\begin{array}{c}0.0117 \\
(0.0789)\end{array}$ & $\begin{array}{c}2.8983 \\
(0.2795)\end{array}$ \\
\hline VOLI & $\begin{array}{c}0.1494 \\
(0.5496)\end{array}$ & $\begin{array}{c}0.4926 \\
(0.0087)\end{array}$ & $\begin{array}{c}0.0079 \\
(0.9720)\end{array}$ & $\begin{array}{l}130.0866 \\
(0.2525)\end{array}$ \\
\hline $\begin{array}{c}\mathrm{R}^{2} \\
\text { Observations }\end{array}$ & $\begin{array}{c}0.3549 \\
32\end{array}$ & $\begin{array}{c}0.6361 \\
32\end{array}$ & $\begin{array}{c}0.2546 \\
32\end{array}$ & $\begin{array}{c}0.7091 \\
23\end{array}$ \\
\hline (Heteroskedasticity-consi & $P$-values in $p$ & arentheses) & & \\
\hline $\begin{array}{l}\text { Notes: GROWTH=real per } \\
\text { growth; PRODUCTIVITY= } \\
\text { savings divided by GDP; LR } \\
\text { logarithm of initial secondar } \\
\text { per year; GOVI=initial gover } \\
\text { inflation rate; BMPI=initial } \\
\text { credit to private enterprises a } \\
\text { volatility. }\end{array}$ & $\begin{array}{l}\text { GDP growth; } \\
\text { WTH-(0.3)(CA } \\
=\text { logarithm of } \\
\text { ool enrollment } \\
\text { tt consumption } \\
\text { market exchan } \\
\text { are of GDP; V }\end{array}$ & $\begin{array}{l}\text { CAPITAL=re } \\
\text { PITAL); SAV } \\
\text { nitial real per } \\
\text { REV=numbe } \\
\text { expenditures } \\
\text { ge rate premil } \\
\text { OLI=initial } m\end{array}$ & $\begin{array}{l}\text { al per capita capital stc } \\
\text { INGS=gross private } \\
\text { capita GDP; LSEC= } \\
\text { of revolutions and co } \\
\text { divided by GDP; PII=i } \\
\text { m; BANKI=initial ba } \\
\text { easure of stock returm }\end{array}$ & $\begin{array}{l}\text { ups } \\
\text { initial } \\
\text { nk }\end{array}$ \\
\hline
\end{tabular}


Table 8--Stock Market Integration (CAPM), Banks, and Growth, 1976-1993, Pooled, Instrumenal Variables

\begin{tabular}{|c|c|c|c|c|}
\hline \multirow[b]{2}{*}{ Independent Variables } & \multicolumn{4}{|c|}{ Dependent Variables } \\
\hline & GROWTH & CAPITAL & PRODUCTIVITY & SAVINGS \\
\hline Constant & $\begin{array}{c}0.0632 \\
(0.0851)\end{array}$ & $\begin{array}{c}0.0314 \\
(0.4874)\end{array}$ & $\begin{array}{c}0.0624 \\
(0.0882)\end{array}$ & $\begin{array}{c}21.1115 \\
(0.0667)\end{array}$ \\
\hline LRGDP & $\begin{array}{c}-0.0098 \\
(0.1459)\end{array}$ & $\begin{array}{c}-0.0018 \\
(0.8373)\end{array}$ & $\begin{array}{c}-0.0111 \\
(0.1137)\end{array}$ & $\begin{array}{c}-0.5100 \\
(0.7835)\end{array}$ \\
\hline LSEC & $\begin{array}{c}0.0223 \\
(0.2619)\end{array}$ & $\begin{array}{c}0.0020 \\
(0.9089)\end{array}$ & $\begin{array}{c}0.0283 \\
(0.2525)\end{array}$ & $\begin{array}{c}5.2072 \\
(0.3170)\end{array}$ \\
\hline REV & $\begin{array}{c}-0.0108 \\
(0.2081)\end{array}$ & $\begin{array}{c}-0.0122 \\
(0.1280)\end{array}$ & $\begin{array}{c}-0.0048 \\
(0.5592)\end{array}$ & $\begin{array}{c}-2.6284 \\
(0.5935)\end{array}$ \\
\hline GOVY & $\begin{array}{c}-0.1985 \\
(0.2268)\end{array}$ & $\begin{array}{c}0.0314 \\
(0.8972)\end{array}$ & $\begin{array}{c}-0.2555 \\
(0.1263)\end{array}$ & $\begin{array}{l}-42.4721 \\
(0.2096)\end{array}$ \\
\hline BMP & $\begin{array}{c}0.0000 \\
(0.9097)\end{array}$ & $\begin{array}{c}-0.0006 \\
(0.0093)\end{array}$ & $\begin{array}{c}0.0001 \\
(0.5136)\end{array}$ & $\begin{array}{c}-0.0142 \\
(0.8239)\end{array}$ \\
\hline BANK & $\begin{array}{c}0.0096 \\
(0.4780)\end{array}$ & $\begin{array}{c}0.0143 \\
(0.4103)\end{array}$ & $\begin{array}{c}0.0032 \\
(0.8145)\end{array}$ & $\begin{array}{l}-4.3598 \\
(0.1908)\end{array}$ \\
\hline CAPM & $\begin{array}{c}-0.0065 \\
(0.1397)\end{array}$ & $\begin{array}{c}-0.0014 \\
(0.7607)\end{array}$ & $\begin{array}{c}-0.0085 \\
(0.0831)\end{array}$ & $\begin{array}{l}-2.0167 \\
(0.3534)\end{array}$ \\
\hline $\begin{array}{c}\text { Observations } \\
\text { (Heteroskedasticity-consi }\end{array}$ & $\begin{array}{r}38 \\
\text { P-values in } p \\
\end{array}$ & $\begin{array}{l}\quad 38 \\
\text { arentheses) }\end{array}$ & 38 & 25 \\
\hline $\begin{array}{l}\text { Notes: GROWTH=real per } \\
\text { growth; PRODUCTIVITY= } \\
\text { divided by GDP; LRGDP=lc } \\
\text { initial secondary school enro } \\
\text { government consumption ex } \\
\text { market exchange rate premit } \\
\text { CAPM=the international cap } \\
\text { Instruments: a constant, the } \\
\text { secondary school enrollment } \\
\text { consumption expenditures di } \\
\text { exchange rate premium, initi } \\
\text { capitalization, initial total va } \\
\text { a share of market capitalizati }\end{array}$ & $\begin{array}{l}\text { GDP growth; } \\
\text { WTH-(0.3)(CA } \\
\text { hm of initial re } \\
\text { t; REV=numb } \\
\text { tures divided b } \\
\text { ANK=bank cr } \\
\text { sset pricing mo } \\
\text { ithm of initial } \\
\text { ber of revoluti } \\
\text { by GDP, initi } \\
\text { ports + import } \\
\text { aded as a share } \\
\text { itial bank cred }\end{array}$ & $\begin{array}{l}\text { CAPITAL=re } \\
\text { PITAL); SAV } \\
\text { al per capita G } \\
\text { er of revolutio } \\
\text { y GDP; PI=in } \\
\text { edit to private } \\
\text { del measure o } \\
\text { real per capita } \\
\text { ons and coups } \\
\text { al inflation rate } \\
\text { s) as a share o } \\
\text { of GDP, initia } \\
\text { it to private en }\end{array}$ & $\begin{array}{l}\text { al per capita capital st } \\
\text { INGS=gross private s } \\
\text { iDP; LSEC=logarithm } \\
\text { ins and coups per year; } \\
\text { flation rate; BMP=bla } \\
\text { enterprises as a share } \\
\text { f stock market integrat } \\
\text { GDP, the logarithm o } \\
\text { per year, initial gover } \\
\text { e, initial black market } \\
\text { f GDP, initial market } \\
\text { al value of stock transa } \\
\text { tterprises as a share of }\end{array}$ & $\begin{array}{l}\text { ock } \\
\text { avings } \\
\text { of } \\
\text { GOVY= } \\
\text { ck } \\
\text { of GDP; } \\
\text { tion. } \\
\text { f initial } \\
\text { nment } \\
\text { ictions as } \\
\text { GDP. }\end{array}$ \\
\hline
\end{tabular}


Table 9--Stock Market Integration (APM), Banks, and Growth, 1976-1993, Pooled, Instrumenal Variables

\begin{tabular}{|c|c|c|c|c|}
\hline \multirow[b]{2}{*}{ Independent Variables } & \multicolumn{4}{|c|}{ Dependent Variables } \\
\hline & GROWTH & CAPITAL & PRODUCTIVITY & SAVINGS \\
\hline Constant & $\begin{array}{c}0.0810 \\
(0.0543)\end{array}$ & $\begin{array}{c}0.0295 \\
(0.5745)\end{array}$ & $\begin{array}{c}0.0830 \\
(0.0520)\end{array}$ & $\begin{array}{c}20.9538 \\
(0.1245)\end{array}$ \\
\hline LRGDP & $\begin{array}{c}-0.0119 \\
(0.1065)\end{array}$ & $\begin{array}{c}-0.0022 \\
(0.7933)\end{array}$ & $\begin{array}{c}-0.0139 \\
(0.0887)\end{array}$ & $\begin{array}{l}-1.4695 \\
(0.4282)\end{array}$ \\
\hline LSEC & $\begin{array}{c}0.0216 \\
(0.2374)\end{array}$ & $\begin{array}{l}-0.0006 \\
(0.9691)\end{array}$ & $\begin{array}{c}0.0260 \\
(0.2289)\end{array}$ & $\begin{array}{c}7.6357 \\
(0.1825)\end{array}$ \\
\hline REV & $\begin{array}{c}-0.0131 \\
(0.0939)\end{array}$ & $\begin{array}{c}-0.0125 \\
(0.0953)\end{array}$ & $\begin{array}{c}-0.0078 \\
(0.3802)\end{array}$ & $\begin{array}{l}-2.0123 \\
(0.6684)\end{array}$ \\
\hline GOVY & $\begin{array}{c}-0.1752 \\
(0.2308)\end{array}$ & $\begin{array}{c}0.0564 \\
(0.8109)\end{array}$ & $\begin{array}{c}-0.2144 \\
(0.1214)\end{array}$ & $\begin{array}{l}-37.7317 \\
(0.2142)\end{array}$ \\
\hline BMP & $\begin{array}{c}0.0000 \\
(0.9915)\end{array}$ & $\begin{array}{c}-0.0006 \\
(0.0086)\end{array}$ & $\begin{array}{c}0.0002 \\
(0.4518)\end{array}$ & $\begin{array}{c}0.0302 \\
(0.6765)\end{array}$ \\
\hline BANK & $\begin{array}{c}0.0148 \\
(0.3058)\end{array}$ & $\begin{array}{c}0.0186 \\
(0.2700)\end{array}$ & $\begin{array}{c}0.0117 \\
(0.4407)\end{array}$ & $\begin{array}{c}-3.8182 \\
(0.1272)\end{array}$ \\
\hline APM & $\begin{array}{l}-0.0075 \\
(0.3225)\end{array}$ & $\begin{array}{c}0.0008 \\
(0.9128)\end{array}$ & $\begin{array}{l}-0.0086 \\
(0.2425)\end{array}$ & $\begin{array}{l}-2.8466 \\
(0.1039)\end{array}$ \\
\hline $\begin{array}{c}\text { Observations } \\
\text { (Heteroskedasticity-consi }\end{array}$ & $\begin{array}{r}38 \\
\text { P-values in } p \\
\end{array}$ & $\begin{array}{c}\quad 38 \\
\text { arentheses) } \\
\end{array}$ & 38 & 25 \\
\hline $\begin{array}{l}\text { Notes: GROWTH=real per } \\
\text { growth; PRODUCTIVITY= } \\
\text { divided by GDP; } L R G D P=10 \\
\text { initial secondary school enro } \\
\text { government consumption ex } \\
\text { market exchange rate premiv } \\
\text { APM=the arbitrage pricing n } \\
\text { Instruments: a constant, the } \\
\text { secondary school enrollment } \\
\text { consumption expenditures di } \\
\text { exchange rate premium, initi } \\
\text { capitalization, initial total va } \\
\text { a share of market capitalizati }\end{array}$ & $\begin{array}{l}\text { a GDP growth; } \\
\text { WTH- }(0.3)(C A \\
\text { thm of initial re } \\
\text { nt; REV=numb } \\
\text { itures divided t } \\
\text { BANK =bank cr } \\
\text { I measure of stt } \\
\text { rithm of initial } \\
\text { nber of revolut } \\
\text { d by GDP, initi } \\
\text { xports + import } \\
\text { raded as a share } \\
\text { nitial bank cred }\end{array}$ & $\begin{array}{l}\text { CAPITAL=r } \\
\text { PITAL); SAI } \\
\text { al per capita } \\
\text { er of revolutic } \\
\text { y GDP; } P I=\text { in } \\
\text { edit to private } \\
\text { ck market int } \\
\text { real per capita } \\
\text { ons and coups } \\
\text { al inflation rat } \\
\text { s) as a share c } \\
\text { of GDP, initi }\end{array}$ & $\begin{array}{l}\text { Eal per capita capital st } \\
\text { INGS=gross private s } \\
\text { FP; LSEC=logarithm } \\
\text { ons and coups per year } \\
\text { flation rate; BMP=bla } \\
\text { enterprises as a share } \\
\text { egration. } \\
\text { GDP, the logarithm o } \\
\text { per year, initial gover } \\
\text { e, initial black market } \\
\text { f GDP, initial market }\end{array}$ & $\begin{array}{l}\text { ock } \\
\text { avings } \\
\text { of } \\
\text {; GOVY= } \\
\text { ck } \\
\text { of GDP; } \\
\text { f initial } \\
\text { nment }\end{array}$ \\
\hline
\end{tabular}


Table 10 - Initial Stock Market Development, Banks and Growth, 78 Country Sample (Dependent Variable: Real Per Capita GDP Growth 1976-1993)

\begin{tabular}{|c|c|c|c|c|c|c|c|c|c|c|}
\hline & \multicolumn{2}{|c|}{ Weight $=1$} & \multicolumn{2}{|c|}{ Weight $=0.75$} & \multicolumn{2}{|c|}{ Weight $=0.50$} & \multicolumn{2}{|c|}{ Weight $=0.25$} & \multicolumn{2}{|c|}{ Weight $=0$} \\
\hline $\begin{array}{l}\text { Stock Market } \\
\text { Indicator (SMI) }\end{array}$ & BANKI & SMI & BANKI & SMI & BANKI & SMI & BANKI & SMI & $\overline{\text { BANKI }}$ & SMI \\
\hline TORI & $\begin{array}{r}0.015 \\
(2.753)\end{array}$ & $\begin{array}{r}0.022 \\
(2.448)\end{array}$ & $\begin{array}{r}0.012 \\
(3.000)\end{array}$ & $\begin{array}{r}0.028 \\
(2.545)\end{array}$ & $\begin{array}{r}0.012 \\
(3.000)\end{array}$ & $\begin{array}{r}0.027 \\
(2.571)\end{array}$ & $\begin{array}{r}0.011 \\
(0.902)\end{array}$ & $\begin{array}{r}0.024 \\
(2.572)\end{array}$ & $\begin{array}{r}0.013 \\
(2.753)\end{array}$ & $\begin{array}{r}0.027 \\
(2.448)\end{array}$ \\
\hline TVTI & $\begin{array}{r}0.013 \\
(2.630)\end{array}$ & $\begin{array}{r}0.111 \\
(4.242)\end{array}$ & $\begin{array}{r}0.011 \\
(2.750)\end{array}$ & $\begin{array}{r}0.116 \\
(5.043)\end{array}$ & $\begin{array}{r}0.010 \\
(2.632)\end{array}$ & $\begin{array}{r}0.027 \\
(2.571)\end{array}$ & $\begin{array}{r}0.010 \\
(2.658)\end{array}$ & $\begin{array}{r}0.105 \\
(4.667)\end{array}$ & $\begin{array}{r}0.014 \\
(2.536)\end{array}$ & $\begin{array}{r}0.098 \\
(3.854)\end{array}$ \\
\hline MCAPI & $\begin{array}{r}0.012 \\
(2.047)\end{array}$ & $\begin{array}{r}0.018 \\
(2.826)\end{array}$ & $\begin{array}{r}0.011 \\
(2.200)\end{array}$ & $\begin{array}{r}0.017 \\
(1.000)\end{array}$ & $\begin{array}{r}0.010 \\
(2.106)\end{array}$ & $\begin{array}{r}0.017 \\
(3.333)\end{array}$ & $\begin{array}{r}0.009 \\
(2.044)\end{array}$ & $\begin{array}{r}0.016 \\
(3.224)\end{array}$ & $\begin{array}{r}0.008 \\
(1.866)\end{array}$ & $\begin{array}{r}0.024 \\
(2.672)\end{array}$ \\
\hline
\end{tabular}

Weighted Least Squares: Indicated weights are given to countries without direct measures of the stock market development indicators. (Heteroskedasticity - consistent t-statistics in parentheses)

Note: BANKI is the value of the ratio of bank credit to private enterprises divided by GDP in 1976. TORI is the ratio of the total value of domestic securities traded on the national exchange divided by market capitalisation. TVTI is the ratio of the total value of domestic securities traded on the national exchange divided by GDP in 1976. (If the 1976 figure is unavailable, the earliest available number is used.) Besides BANKI and the indicated stock market indicator (SMI), the above regressions also include as explanatory variables the logarithm of initial real per capital GDP, the logarithm of initial secondary school enrollment, the number of revolutions and coups over the sample period, the initial values of government consumption expenditure divided by GDP, inflation, and the black market exchange rate premium. 



\section{Policy Research Working Paper Series}

Title

WPS1665 How Important Are Labor Markets to the Welfare of Indonesia's Poor?

WPS1666 Is Growth in Bangladesh's Rice Production Sustainable?

WPS1667 Dealing with Commodity Price Uncertainty

WPS1668 Small is Beautiful: Preferential Trade Agreements and the Impact of Country Size, Market Share, Efficiency, and Trade Policy

WPS1669 International Capital Flows: Do Short-Term Investment and Direct Investment Differ?

WPS1670 Assessing the Welfare Impacts of Public Spending

WPS1671 Financial Constraints, Uses of Funds, and Firm Growth: An International Comparison

WPS1672 Controlling Industrial Pollution: A New Paradigm

WPS1673 Indonesian Labor Legislation in a Comparative Perspective: A Study of Six APEC Countries

WPS1674 How Can China Provide Income Security for Its Rapidly Aging Population?

WPS1675 Nations, Conglomerates, and Empires: The Tradeoff between Income and Sovereignty

WPS1676 The Evolution of Payments in Europe, Japan, and the United States: Lessons for Emerging Market Economies

WPS1677 Reforming Indonesia's Pension System
Author

Andrew D. Mason

Jacqueline Baptist

John Baffes

Madhur Gautam

Panos Varangis

Don Larson

Maurice Schiff

Punam Chuhan

Gabriel Perez-Quiros

Helen Popper

Dominique van de Walle

Asli Demirgüç-Kunt

Vojislav Maksimovic

Shakeb Afsah

Bemoit Laplante

David Wheeler

Reema Nayar

Barry Friedman

Estelle James

Cheikh Kane

Monika Queisser

Branko Milanovic

David B. Humphrey

Setsuya Sato

Masayoshi Tsurumi

Jukka M. Vesala

Chad Leechor
Date

October 1996

October 1996

October 1996

October 1996

October 1996

October 1996

October 1996

October 1996

October 1996

October 1996

October 1996

October 1996

October 1996
S. Khan 33651

Contact

for paper

D. Ballantyne 87198

P. Kokila 33716

J. Jacobson 33710

M. Patena 39515

T. Nadora 33925

C. Bernardo 31148

P. Sintim-Aboagye 37644

D. Wheeler 33401

R. Nayar 33468

S. Khan 33651

$T$. Ishibe 38968

G. Telahun 82407 
Policy Research Working Paper Series

\begin{tabular}{|c|c|c|c|c|}
\hline & Title & Author & Date & $\begin{array}{l}\text { Contact } \\
\text { for paper }\end{array}$ \\
\hline WPS1678 & $\begin{array}{l}\text { Financial Development and Economic } \\
\text { Growth: Views and Agenda }\end{array}$ & Ross Levine & October 1996 & $\begin{array}{l}\text { P. Sintim-Aboagye } \\
38526\end{array}$ \\
\hline WPS1679 & $\begin{array}{l}\text { Trade and the Accumulation and } \\
\text { Diffusion of Knowledge }\end{array}$ & Pier Carlo Padoan & November 1996 & $\begin{array}{l}\text { M. Pateña } \\
39515\end{array}$ \\
\hline WPS1680 & $\begin{array}{l}\text { Brazil's Efficient Payment System: } \\
\text { A Legacy of High Inflation }\end{array}$ & $\begin{array}{l}\text { Robert Listfield } \\
\text { Fernando Montes-Negret }\end{array}$ & November 1996 & $\begin{array}{l}\text { T. Ishibe } \\
38968\end{array}$ \\
\hline WPS1681 & India in the Global Economy & $\begin{array}{l}\text { Milan Brahmbhatt } \\
\text { T. G. Srinivasan } \\
\text { Kim Murrell }\end{array}$ & November 1996 & $\begin{array}{l}\text { S. Crow } \\
30763\end{array}$ \\
\hline WPS1682 & $\begin{array}{l}\text { Is the "Japan Problem" Real? } \\
\text { How Problems in Japan's Financial } \\
\text { Sector Could Affect Developing } \\
\text { Regions }\end{array}$ & $\begin{array}{l}\text { Shigeru Otsubo } \\
\text { Masahiko Tsutsumi }\end{array}$ & November 1996 & $\begin{array}{l}\text { J. Queen } \\
33740\end{array}$ \\
\hline WPS1683 & $\begin{array}{l}\text { High Real Interest Rates, Guarantor } \\
\text { Risk, and Bank Recapitalizations }\end{array}$ & Philip L. Brock & November 1996 & $\begin{array}{l}\text { N. Castillo } \\
33490\end{array}$ \\
\hline WPS1684 & $\begin{array}{l}\text { The Whys and Why Nots of Export } \\
\text { Taxation }\end{array}$ & $\begin{array}{l}\text { Shantayanan Devarajan } \\
\text { Delfin Go } \\
\text { Maurice Schiff } \\
\text { Sethaput Suthiwart-Naruept }\end{array}$ & November 1996 & $\begin{array}{l}\text { C. Bernardo } \\
37699\end{array}$ \\
\hline WPS1685 & $\begin{array}{l}\text { Macroeconomic Crises and Poverty } \\
\text { Monitoring: A Case Study for India }\end{array}$ & $\begin{array}{l}\text { Gaurav Datt } \\
\text { Martin Ravallion }\end{array}$ & November 1996 & $\begin{array}{l}\text { P. Sader } \\
33902\end{array}$ \\
\hline WPS1686 & $\begin{array}{l}\text { Institutions, Financial Markets, and } \\
\text { Firms' Choice of Debt Maturity }\end{array}$ & $\begin{array}{l}\text { Asli Demirgüç-Kunt } \\
\text { Vojislav Maksimovic }\end{array}$ & November 1996 & $\begin{array}{l}\text { P. Sintim-Aboagye } \\
37644\end{array}$ \\
\hline WPS1687 & Regionalism versus Multilateralism & L. Alan Winters & November 1996 & $\begin{array}{l}\text { A. Kitson-Walters } \\
33712\end{array}$ \\
\hline WPS1688 & $\begin{array}{l}\text { Risk, Taxpayers, and the Role of } \\
\text { Government in Project Finance }\end{array}$ & Michael Klein & December 1996 & $\begin{array}{l}\text { S. Vivas } \\
82809\end{array}$ \\
\hline WPS1689 & $\begin{array}{l}\text { Is Economic Analysis of Projects } \\
\text { Still Useful? }\end{array}$ & Pedro Belli & December 1996 & $\begin{array}{l}\text { K. Schrader } \\
82736\end{array}$ \\
\hline WPS1690 & $\begin{array}{l}\text { Stock Markets, Banks, and Economic } \\
\text { Growth }\end{array}$ & $\begin{array}{l}\text { Ross Levine } \\
\text { Sara Zervos }\end{array}$ & December 1996 & $\begin{array}{l}\text { P. Sintim-Aboagye } \\
38526\end{array}$ \\
\hline
\end{tabular}

